\title{
The Role of Bi-doping in Promoting Electron Transfer and Catalytic Performance of Pt/3DOM-Ce ${ }_{1-\mathrm{x}} \mathrm{Bi}_{\mathrm{x}} \mathrm{O}_{2-\delta}$
}

Kai Yu, ${ }^{[a] b][c]}$ Da Lei, ${ }^{[a][b]}$ Yajun Feng, ${ }^{[a]}$ Yue Chang, ${ }^{[b]}$ Haochen $Y u,{ }^{[b]}$ Yanbing Wang, ${ }^{[b]}$ Yaqi Liu, ${ }^{[\mathrm{a}]}$ Gui-Chang Wang, ${ }^{[\mathrm{d}]}$ Lan-Lan Lou, ${ }^{[\mathrm{bb}][\mathrm{c}]}$ Shuangxi Liu, ${ }^{*[\mathrm{~b}]}$ Wuzong Zhou*[c]

[a] MOE Key Laboratory of Pollution Processes and Environmental Criteria, College of Environmental Science and Engineering, Nankai University, Tianjin 300350, China

${ }^{[b]}$ Institute of New Catalytic Materials Science and MOE Key Laboratory of Advanced Energy Materials Chemistry, School of Materials Science and Engineering, National Institute of Advanced Materials, Nankai University, Tianjin 300350, China

${ }^{[c]}$ School of Chemistry, University of St Andrews, St Andrews, Fife KY16 9ST, United Kingdom

${ }^{\text {[d] }}$ College of Chemistry, Nankai University, Tianjin 300071, China

Corresponding authors:

E-mail: 1llou@nankai.edu.cn (L.-L Lou), sxliu@nankai.edu.cn (S. Liu),wzhou@st-andrews.ac.uk (W. Z. Zhou) 


\begin{abstract}
:
Investigation of $\mathrm{Bi}$-doping effect on catalytic performance of $\mathrm{Pt} / 3 \mathrm{DOM}-\mathrm{Ce}_{1-\mathrm{x}} \mathrm{Bi}_{\mathrm{x}} \mathrm{O}_{2-\delta}$ in the aerobic oxidation of 5-hydroxymethyl-2-furfural allows us to reveal the promoted catalytically active sites: the asymmetrical oxygen vacancies coordinated with one $\mathrm{Bi}$ and up to three $\mathrm{Ce}$ cations, e.g. $\mathrm{Bi}$ $\square(-\mathrm{Ce})_{3}$, which can easily gain oxygen atoms in favor of the $\mathrm{CeO}_{2}$ structure, and, when filled by oxygen, easily release oxygen anions in favor of six coordination for $\mathrm{Bi}^{3+}$. The loss of electrons in the reduction of oxygen atoms at these sites would be replenished by electron transfer from Pt nanoparticles, eventually promoting the oxidation potential of the Pt nanoparticles. The present work points out that the promoted catalytic properties in $\mathrm{Bi}$-doped $\mathrm{CeO}_{2}$ is mainly due to the asymmetric structures of the oxygen vacancies, rather than simply to the number of the oxygen vacancies. The newly proposed model of asymmetrical active sites and electron transfer mechanism may shed light on the future investigation of the physico-chemical properties of other solid solution substrate supported metal nanoparticle catalysts.
\end{abstract}

Keywords: Asymmetric oxygen vacancy; Electron transfer; Promoting mechanism; Aerobic oxidation; 5-hydroxymethyl-2-furfural 


\section{Introduction}

Supported metal nanocatalysts are commonly used in chemical industry and have been investigated extensively. However, to identify the active sites and to understand electron transfer process in between the metal nanoparticles and the substrates are still challenging targets. ${ }^{[1-3]}$ To evade the extreme difficulties of direct detection of the catalytically active sites and the charge transfer, we tried to gain the relevant information of changes in structures of catalysts and in catalytic activity of selected reactions, to reveal the active sites via an indirect method. The first selected example was $\mathrm{Pt}$ nanocatalyst supported by $\mathrm{Bi}$-doped $\mathrm{CeO}_{2-\delta}$ used for aerobic oxidation of 5-hydroxymethyl-2-furfural (HMF).

As far as practical catalysts are considered, $\mathrm{CeO}_{2}$ and its ternary oxides, as efficient catalysts or catalyst carriers, have been widely used in many catalytic systems. ${ }^{[4]}$ The low redox potential between $\mathrm{Ce}^{3+}$ and $\mathrm{Ce}^{4+}(1.3 \sim 1.8 \mathrm{~V})$ and high oxygen-storage-capacity allow $\mathrm{CeO}_{2}$-based catalysts to exhibit promising catalytic activity for aerobic oxidation of various reactants, such as $\mathrm{CO},{ }^{[5,6]}$ soot, ${ }^{[7,8]}$ and alcohols. ${ }^{[9,10]}$

The biomass-derived HMF is considered as an important intermediate from renewable biomass to industrial chemicals. It can be obtained from inexpensive and plentiful cellulosic derivatives, such as fructose, glucose, and cellulose, ${ }^{[11-13]}$ and can be converted to a series of important chemical compounds through aerobic oxidation, e.g. 2,5-diformylfuran (DFF), 5hydroxymethyl-2-furancarboxylic acid (HMFCA), 5-formyl-2-furancarboxylic acid (FFCA), 2,5furandicarboxylic acid (FDCA), etc. ${ }^{[14,15]}$ Especially, its oxidation product, FDCA, is one of the selected top value added platform chemicals from biomass, and can be used as a monomer for the production of new polyesters and nylons. ${ }^{[16]}$ Metal oxide supported noble metal nanocatalysts are considered as a kind of efficient and promising catalysts for the aerobic oxidation of HMF towards 
FDCA. ${ }^{[17-19]}$ Among them, $\mathrm{CeO}_{2}$ supported $\mathrm{Au},{ }^{[20-22]} \mathrm{Pt},{ }^{[23]}$ or $\mathrm{Au}-\mathrm{Cu}$ alloy ${ }^{[20]}$ nanocatalysts exhibited notably enhanced catalytic performance in comparison with catalysts using other oxide carriers. Moreover, the $\mathrm{Bi}$-doped $\mathrm{CeO}_{2}$, as an efficient carrier, can further improve their catalytic properties. ${ }^{[21,23]}$ Although it is believed that the promotion of the catalytic properties using $\mathrm{CeO}_{2}$ as catalyst carrier is mainly attributed to a large amount of oxygen vacancies on the surface of the oxides, giving a true composition of $\mathrm{CeO}_{2-\delta}$, till now, our understanding of the role of oxygen vacancies and possible charge transfer in between the metal particles and the carriers is still superficial.

In the present work, a series of three-dimensionally ordered macroporous (3DOM) $\mathrm{Ce}_{1-\mathrm{x}} \mathrm{Bi}_{\mathrm{x}} \mathrm{O}_{2-\delta}$ were fabricated using polymethylmethacrylate (PMMA) colloidal crystals as template and employed as catalyst carriers to support Pt nanoparticles. We found that the macroporous structure of these specimens could indeed greatly facilitate the mass transfer. More importantly, significant promotions of electron transfer from $\mathrm{Pt}$ nanoparticles to $\mathrm{Bi}$-doped $\mathrm{CeO}_{2-\delta}$ and catalytic performance of these catalysts in the aerobic oxidation of HMF were observed in comparison with the Bi-free catalyst. We infer based on the experimental data that the asymmetrical vacancy sites, represented by $\mathrm{Bi}-\square(-\mathrm{Ce})_{3}$, have different properties from the symmetrical vacancy sites, e.g. (Ce- $)_{2} \square(-\mathrm{Ce})_{2}$ and (Bi- $)_{2} \square(-\mathrm{Bi})_{2}$, where $\square$ represents an oxygen vacancy. The role of Bi-doping in the catalytic process is elucidated in a proposed mechanism, which may be used for explanation of many other nanoscale catalysts supported by metal oxides, where an interaction between the surface nanoparticles and the oxide support is significant.

\section{Experimental Section}

\subsection{Materials.}


All chemicals were obtained from commercial source and without further purification. HMF (97\%) and FDCA (98\%) were purchased from Heowns Biochemical Technology Co., Ltd. HMFCA (98\%) was obtained from Matrix Scientific. DFF (98\%) was provided by Sun Chemical Technology Co., Ltd. FFCA (98\%) was supplied by Toronto Research Chemicals Inc. In quantitative analysis of chromatogram, the above specimens were used as the standards. Methanol, potassium persulfate (KPS, $\mathrm{K}_{2} \mathrm{~S}_{2} \mathrm{O}_{8}$ ), and sodium bicarbonate were obtained from Sinopharm Chemical Reagent Co., Ltd. Polyvinylpyrrolidone (PVP, MW = 58000) was obtained from Tianjing Guangfu Fine Chemistry Research Institute. Methyl methacrylate (MMA), ethylene glycol, ascorbic acid, cerium(III) nitrate hexahydrate $\left(\mathrm{Ce}\left(\mathrm{NO}_{3}\right)_{3} \cdot 6 \mathrm{H}_{2} \mathrm{O}\right)$, bismuth(III) nitrate pentahydrate $\left(\mathrm{Bi}\left(\mathrm{NO}_{3}\right)_{3} \cdot 5 \mathrm{H}_{2} \mathrm{O}\right)$, and chloroplatinic acid hexahydrate $\left(\mathrm{H}_{2} \mathrm{PtCl}_{6} \cdot 6 \mathrm{H}_{2} \mathrm{O}\right)$ were purchased from Aladdin Chemicals Co., Ltd.

\subsection{Characterization methods.}

Powder X-ray diffraction (XRD) patterns were recorded on a Rigaku SmartLab $3 \mathrm{~kW}$ diffractometer with $\mathrm{Cu} \mathrm{K} \mathrm{K}_{\alpha} \mathrm{X}$-ray $(\lambda=1.541 \AA)$ operating at $40 \mathrm{kV}$ and $40 \mathrm{~mA}$, in a $2 \theta$ range of $20^{\circ}$ to $90^{\circ}$ with a scanning rate of $6^{\circ} \mathrm{min}^{-1}$. $\mathrm{N}_{2}$ sorption analysis was carried out on a Micromeritics TriStar 3000 analyzer. The pore-size distribution was calculated according to the Barrett-JoynerHalenda $(\mathrm{BJH})$ method and the surface area was determined by Brunauer-Emmett-Teller (BET) method. FEI Tecnai G2 F20 transmission electron microscopy (TEM) and JEOL JSM-7500F fieldemission scanning electron microscopy (SEM) equipped with an energy dispersive X-ray spectrometry (EDS) were used to observe the morphological and structural features of the produced specimens. Inductively coupled plasma atomic emission spectrometry (ICP-AES) analysis was performed on an IRIS Intrepid II XSP instrument from Thermo Fisher Scientific Inc. X-ray photoelectron spectrometry (XPS) characterization was carried out using a Kratos Axis 
Ultra DLD spectrometer employing a monochromatic Al $\mathrm{K}_{\alpha} \mathrm{X}$-ray source $(h v=1486.6 \mathrm{eV})$ and the binding energy was corrected using the $\mathrm{C} 1 \mathrm{~s}$ peak $(\mathrm{BE}=284.6 \mathrm{eV})$ of carbon contaminants as an internal standard. Raman spectra were collected on a Renishaw inVia model Raman microscope with a CCD detector (Renishaw Ltd., UK). The samples were excited using radiation at $514.5 \mathrm{~nm}$. $\mathrm{H}_{2}$-temperature programmed reduction $\left(\mathrm{H}_{2}-\mathrm{TPR}\right)$ and pulse $\mathrm{CO}$ chemisorption experiments were carried out on a Micromeritics ChemiSorb 2750 analyzer with a thermal conductivity detector. An Agilent 1200 series high-performance liquid chromatograph (HPLC) equipped with a Waters Atlantis T3 column and a UV-Vis detector operating at $271 \mathrm{~nm}$ was used to analyze the reaction solution. $\mathrm{A} \mathrm{H}_{3} \mathrm{PO}_{4}$ aqueous solution $\left(1 \mathrm{mmol} \mathrm{L}^{-1}\right)$ was used as the mobile phase at a flow rate of $0.6 \mathrm{~mL} \mathrm{~min}^{-1}$.

\subsection{Synthesis of $\mathrm{Ce}_{1-x} \mathrm{Bi}_{x} \mathrm{O}_{2-\delta}$ materials.}

$\mathrm{Ce}_{1-\mathrm{x}} \mathrm{Bi}_{\mathrm{x}} \mathrm{O}_{2-\delta}$ materials with $3 \mathrm{DOM}$ structure were synthesized using PMMA colloidal crystal (Figure S1) as a template. The PMMA colloidal crystal template with an average diameter of ca. $300 \mathrm{~nm}$ was synthesized through an emulsifier-free emulsion polymerization technique according to our previous work. ${ }^{[24]}$

In a typical synthesis process of $3 \mathrm{DOM}-\mathrm{Ce}_{1-\mathrm{x}} \mathrm{Bi}_{\mathrm{x}} \mathrm{O}_{2-\delta}$ materials, ethylene glycol $(2 \mathrm{~mL})$, methanol $(7 \mathrm{~mL})$, nitric acid $(1 \mathrm{~mL}, 68 \mathrm{wt} \%)$, and ascorbic acid $(10 \mathrm{mmol})$ were dissolved in deionized water $\left(10 \mathrm{~mL}\right.$ ). $\mathrm{Ce}\left(\mathrm{NO}_{3}\right)_{3} \cdot 6 \mathrm{H}_{2} \mathrm{O}$ and $\mathrm{Bi}\left(\mathrm{NO}_{3}\right)_{3} \cdot 5 \mathrm{H}_{2} \mathrm{O}$ (with mole numbers $n_{\mathrm{Bi}}+n_{\mathrm{Ce}}=10$ mmol) with a selected ratio were added into this solution. After $3 \mathrm{~h}$ stirring at room temperature, PMMA colloidal crystal $(8.0 \mathrm{~g})$ was soaked into this prepared solution for $3 \mathrm{~h}$. Following a filtration and vacuum drying process, the yellowish sample was calcined in an air flow $(80 \mathrm{~mL}$ $\mathrm{min}^{-1}$ ) at a ramp of $1{ }^{\circ} \mathrm{C} \mathrm{min}^{-1}$ from room temperature to $550{ }^{\circ} \mathrm{C}$ and maintained at this temperature for $4 \mathrm{~h}$ to remove the template. The $3 \mathrm{DOM}-\mathrm{Ce}_{1-\mathrm{x}} \mathrm{Bi}_{\mathrm{x}} \mathrm{O}_{2-\delta}(\mathrm{x}=0,0.1,0.2,0.3)$ materials with 
different $\mathrm{Bi}^{3+}$ doping levels were obtained. For comparison, the nanosized $\mathrm{Ce}_{1-x} \mathrm{Bi}_{\mathrm{x}} \mathrm{O}_{2-\delta}$ samples were prepared using the same method, but in the absence of PMMA colloidal crystal template. The obtained samples were designated as $\mathrm{Ce}_{1-\mathrm{x}} \mathrm{Bi}_{\mathrm{x}} \mathrm{O}_{2-\delta}(\mathrm{x}=0,0.1,0.2,0.3)$.

\subsection{Synthesis of Pt/3DOM-Ce $e_{1-x} B i_{x} O_{2-\delta}$ catalysts.}

3DOM-Ce ${ }_{1-x} \mathrm{Bi}_{\mathrm{x}} \mathrm{O}_{2-\delta}$ or $\mathrm{Ce}_{1-\mathrm{x}} \mathrm{Bi}_{\mathrm{x}} \mathrm{O}_{2-\delta}(0.15 \mathrm{~g})$ was dispersed into an aqueous solution of $\mathrm{H}_{2} \mathrm{PtCl}_{6} \cdot 6 \mathrm{H}_{2} \mathrm{O}\left(1.59 \mathrm{~mL}, 5.0 \mathrm{mg} \mathrm{mL}^{-1}\right)$ under stirring in an ultrasonic bath for $10 \mathrm{~min}$, and the resulted mixture was continually stirred for another $5 \mathrm{~h}$. An ethylene glycol solution of PVP $(0.31$ mmol in $40 \mathrm{~mL}$ ) was then added into the mixture. After further stirring for $30 \mathrm{~min}$, the reaction mixture was heated to $130{ }^{\circ} \mathrm{C}$ and aged for $4 \mathrm{~h}$ to ensure completion of the reaction. The product was centrifuged and washed several times with absolute ethanol, and dried at $55^{\circ} \mathrm{C}$ for $12 \mathrm{~h}$. The obtained catalysts were designated as $\mathrm{Pt} / 3 \mathrm{DOM}-\mathrm{Ce}_{1-\mathrm{x}} \mathrm{Bi}_{\mathrm{x}} \mathrm{O}_{2-\delta}$ and $\mathrm{Pt} / \mathrm{Ce}_{1-\mathrm{x}} \mathrm{Bi}_{\mathrm{x}} \mathrm{O}_{2-\delta}$, respectively. The nominal Pt content in these catalysts was $2 \mathrm{wt} \%$, while the results of ICP-AES characterization indicated that the actual Pt loading was about $1.88 \mathrm{wt} \%$.

\subsection{Oxidation of $\mathrm{HMF}$.}

The catalyst $(0.039 \mathrm{~g})$ was added into a solution of $\mathrm{HMF}(0.40 \mathrm{mmol})$ and $\mathrm{NaHCO}_{3}(1.6$ $\mathrm{mmol})$ in deionized water $(20 \mathrm{~mL})$. The suspension was heated to $90{ }^{\circ} \mathrm{C}$ under stirring and bubbled with $\mathrm{O}_{2}$ at a flow rate of $70 \mathrm{~mL} \mathrm{~min}{ }^{-1}$. An aliquot $(50 \mu \mathrm{L})$ of the reaction mixture was taken out at given intervals and diluted to $5 \mathrm{~mL}$ with deionized water in a volumetric flask. The liquid sample was then syringe-filtered through a $0.2 \mu \mathrm{m}$ PTFE membrane and analyzed by HPLC. The concentrations of HMF, HMFCA, FFCA and FDCA in the reaction solutions were measured by HPLC using the external standard calibration curve method. In order to evaluate the relative standard deviation (RSD) of the reaction results, four parallel experiments were carried out by 
using $\mathrm{Pt} / 3 \mathrm{DOM}-\mathrm{Ce}_{0.8} \mathrm{Bi}_{0.2} \mathrm{O}_{2-\delta}$ as catalyst. The RSD values for yield of HMFCA, FFCA and FDCA were determined as $1.7 \%, 2.4 \%$ and $2.5 \%$, respectively.

\subsection{Computational methods.}

The DFT $+\mathrm{U}$ calculation using the Vienna ab initio simulation package (VASP) ${ }^{[25,26]}$ was introduced to investigate the thermodynamic properties of obtained solid solution samples. All calculations in this work used the generalized gradient approximation (GGA-PW91) ${ }^{[27]}$ as the exchange-correlation functional, and energy cutoff of $500 \mathrm{eV}$ was used for the plane-wave expansion of the electronic wave function. The DFT $+\mathrm{U}$ method evaluated the on-site coulomb and exchange interactions in the localized $4 \mathrm{f}$ orbital electrons of Ce by adding an effective HubbardU parameter to repulse electrons on the same orbitals. ${ }^{[28,29]}$ It was reported that the theoretical $U$ value was $5 \mathrm{eV} \cdot{ }^{[30,31]}$ The $\mathrm{p}(2 \sqrt{ } 3 \times 3)$ slab models of $\mathrm{Ce}(111)$ with top four atomic layers relaxed and bottom three layers fixed were used in the present work, the corresponding k-point meshes were set to $2 \times 2 \times 1$. The vacuum space was set to $20 \AA$ between the slabs to minimize their interaction.

\section{Results and Discussion}

\subsection{Characterization of $3 D O M-C e_{1-x} B i_{x} O_{2-\delta}$ specimens.}

Initial characterization of the $3 \mathrm{DOM}-\mathrm{Ce}_{1-\mathrm{x}} \mathrm{Bi}_{\mathrm{x}} \mathrm{O}_{2-\delta}$ samples was by using $\mathrm{XRD}$ as shown in Figure 1. All the diffraction peaks can be indexed onto a $\mathrm{CeO}_{2}$-like unit cell, with a peak shift to a lower angle region corresponding to the Bi-doping, indicating a solid solution state in the whole compositional range up to the Bi-doping of $30 \%$. This can be understood since the high temperature phase, $\delta-\mathrm{Bi}_{2} \mathrm{O}_{3}$, has also a fluorite structure with $25 \%$ oxygen vacancies, which can be stabilized at room temperature in a form of solid solution with less oxygen vacancies. ${ }^{[32]}$ In addition, the wide peaks of these patterns indicate that the crystal sizes are quite small. 


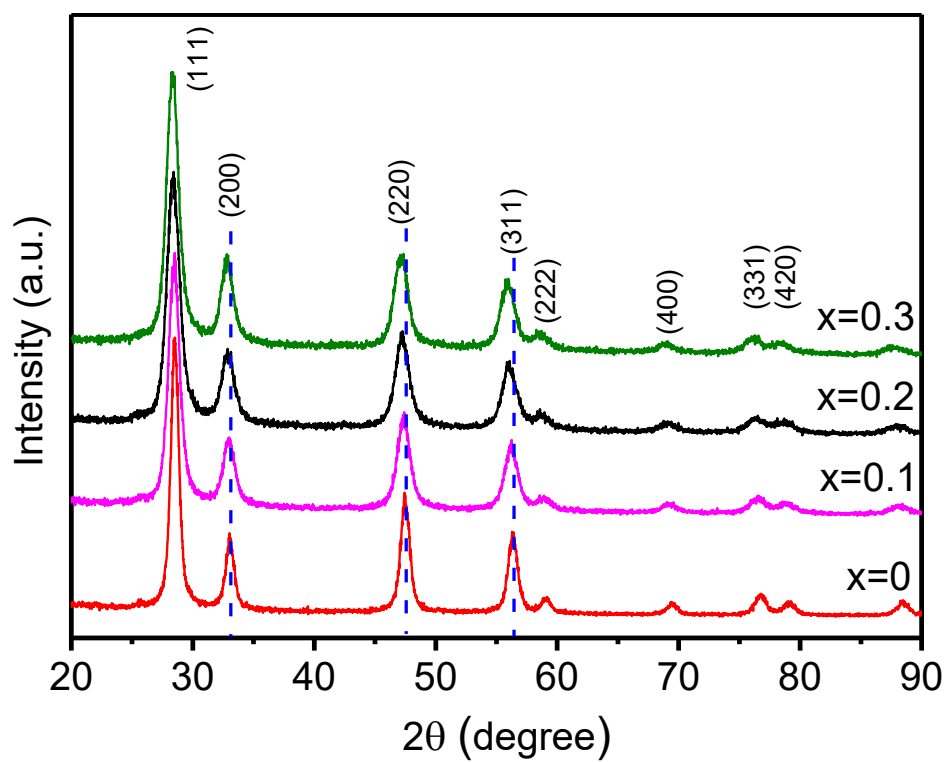

Figure 1. XRD patterns of the $3 \mathrm{DOM}-\mathrm{Ce}_{1-\mathrm{x}} \mathrm{Bi}_{\mathrm{x}} \mathrm{O}_{2-\delta}$ specimens with $\mathrm{x}$ from 0 to 0.3 . The diffraction peaks are indexed to the $\mathrm{CeO}_{2}$-like face-centered cubic unit cell with $a=0.5416 \mathrm{~nm}$ (JCPDS 340394). The dashed lines mark the peak positions of the $x=0$ sample.

Typical SEM image of $3 \mathrm{DOM}-\mathrm{Ce}_{1-\mathrm{x}} \mathrm{Bi}_{\mathrm{x}} \mathrm{O}_{2-\delta}(\mathrm{x}=0.2)$ is shown in Figure 2a. More SEM images of $3 \mathrm{DOM}-\mathrm{Ce}_{1-\mathrm{x}} \mathrm{Bi}_{\mathrm{x}} \mathrm{O}_{2-\delta}$ at lower magnifications are shown in Figure $\mathrm{S} 2$. It can be seen from these images that a well-ordered array of cages, with an inverse opal structure, appears in the porous specimens. A typical diameter of the cages (negative replica of the close packed PMMA colloidal spheres) is about $160 \mathrm{~nm}$, implying a shrinkage of ca. $47 \%$ in comparison with the size of PMMA spheres. The cages are inter-connected via open windows about $78 \mathrm{~nm}$ in diameter, and the average thickness of cage wall is about $23 \mathrm{~nm}$. EDS elemental mapping of $3 \mathrm{DOM}-\mathrm{Ce}_{0.8} \mathrm{Bi}_{0.2} \mathrm{O}_{2}$ $\delta$ exhibits even distributions of both $\mathrm{Ce}$ and $\mathrm{Bi}$ elements in this solid solution material as shown in Figure $2 b$. 

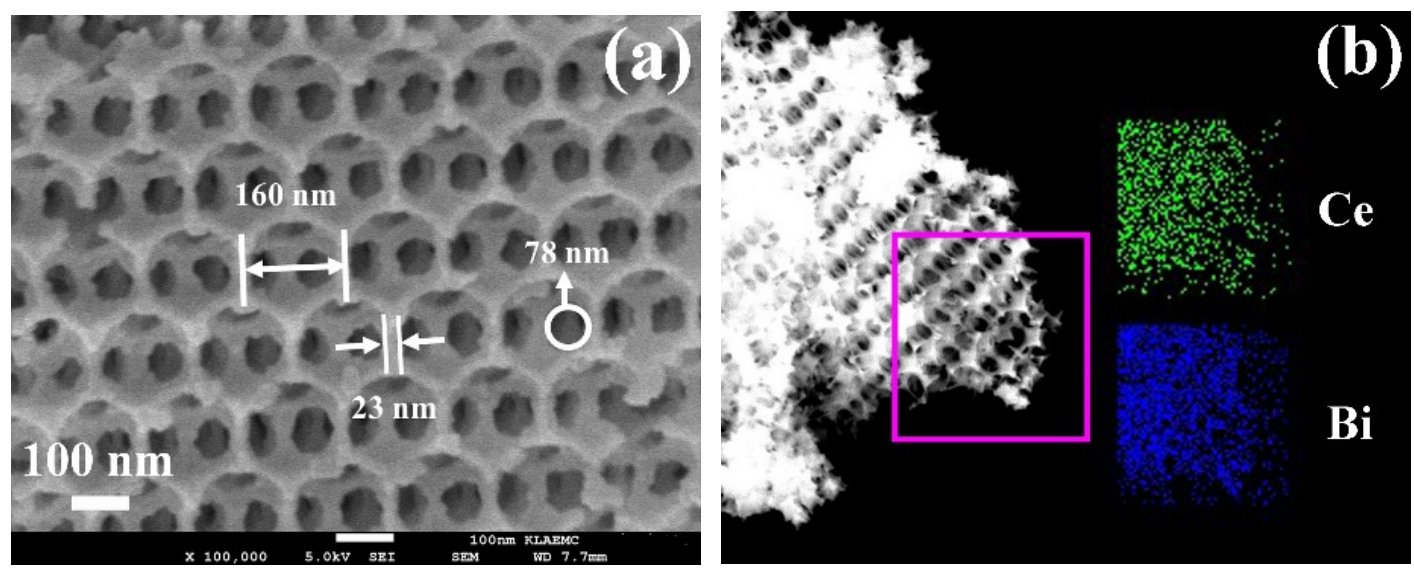

Figure 2. (a) SEM image and (b) EDS elemental mapping of $3 \mathrm{DOM}-\mathrm{Ce}_{0.8} \mathrm{Bi}_{0.2} \mathrm{O}_{2-\delta}$. The dimensions of the cage, inter-cage window and the wall thickness are marked in (a).

The macroporous structure and specific surface areas of these $3 \mathrm{DOM}-\mathrm{Ce}_{1-\mathrm{x}} \mathrm{Bi}_{\mathrm{x}} \mathrm{O}_{2-\delta}$ materials were measured by nitrogen sorption method. The type II characteristic isotherms with an H3 hysteresis loop in the relative pressure $\left(\mathrm{p} / \mathrm{p}_{0}\right)$ range of $0.8 \sim 1.0$ were observed from $3 \mathrm{DOM}-\mathrm{Ce}_{1}$ ${ }_{x} \mathrm{Bi}_{\mathrm{x}} \mathrm{O}_{2-\delta}$, indicating the existence of macroporous structure. The BET surface areas of the 3DOM$\mathrm{Ce}_{1-\mathrm{x}} \mathrm{Bi}_{\mathrm{x}} \mathrm{O}_{2-\delta}$ specimens are in a range of $30 \sim 42 \mathrm{~m}^{2} \mathrm{~g}^{-1}$ (Figure $\mathrm{S} 3$ and Table $\mathrm{S} 1$ ).

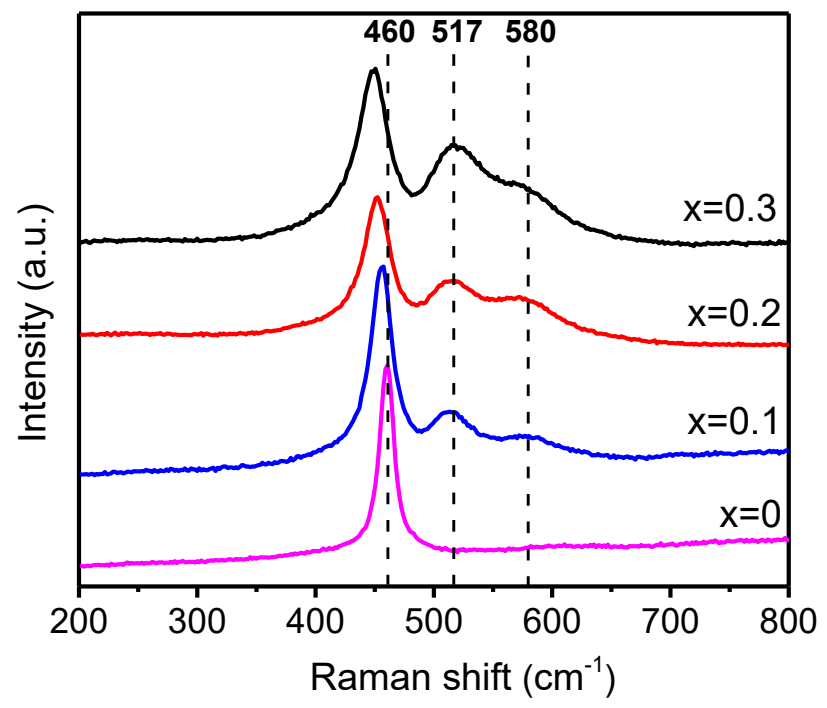

Figure 3. Raman spectra of the $3 \mathrm{DOM}-\mathrm{Ce}_{1-\mathrm{x}} \mathrm{Bi}_{\mathrm{x}} \mathrm{O}_{2-\delta}$ specimens with $\mathrm{x}$ from 0 to 0.3 . 
$\mathrm{Bi}^{3+}$ cations have six coordination of oxygen in the fluorite-type $\delta-\mathrm{Bi}_{2} \mathrm{O}_{3}$, leaving two oxygen vacancies in the eight coordinated environment. In the present work, Raman spectroscopy was used to detect any possible local distortion induced by such Bi-doping (Figure 3). The spectrum of $\mathrm{Bi}$-free $\mathrm{CeO}_{2}$ displays a strong peak at $460 \mathrm{~cm}^{-1}$, which is assigned to the $\mathrm{F}_{2 \mathrm{~g}}$ vibrational mode of cubic fluorite structure of $\mathrm{CeO}_{2} \cdot{ }^{[33]} \mathrm{With}$ the $\mathrm{Bi}^{3+}$-doping, this peak slightly red-shifts to a lower wavenumber, suggesting an obvious variation of the $\mathrm{Ce}-\mathrm{O}$ bonding symmetry. ${ }^{[34]}$ The peak at $517 \mathrm{~cm}^{-1}$, being absent in pure $\mathrm{CeO}_{2}$ and increasing its intensity with the $\mathrm{Bi}$-doping, can be assigned to $\mathrm{BiO}_{6}$ octahedral units in fluorite-type $\mathrm{CeO}_{2}$ structure. This peak was also detected from fluorite-type $\delta-\mathrm{Bi}_{2} \mathrm{O}_{3} \cdot{ }^{[35,36]}$ The peak at $580 \mathrm{~cm}^{-1}$, also absent in pure $\mathrm{CeO}_{2}$, can be assigned to $\mathrm{Ce}^{3+}-\mathrm{O}$ bonds associated with the asymmetric $\mathrm{Bi}^{3+}-\square\left(-\mathrm{Ce}^{3+}\right)_{3}$ sites. ${ }^{[37]}$ The curve fitting of the Raman spectra (Figure S4a-c) suggests that $3 \mathrm{DOM}-\mathrm{Ce}_{0.8} \mathrm{Bi}_{0.2} \mathrm{O}_{2-\delta}$ has the largest amount of $\mathrm{Ce}^{3+}$ among these specimens.

To further quantitatively determine the concentration of $\mathrm{Ce}^{3+}$, which normally co-exist with oxygen vacancies, Ce $3 \mathrm{~d}$ and $\mathrm{O} 1 \mathrm{~s}$ XPS spectra of these catalysts were measured. Ten characteristic peaks are observed in the Ce $3 \mathrm{~d}$ curves (Figure 4a). The five peaks centered at 880.6, 882.2, 885.3, 888.8 , and $898.0 \mathrm{eV}$, corresponding to $\mathrm{v}_{0}, \mathrm{v}, \mathrm{v}$,, $\mathrm{v}$ ', and v'", respectively, can be attributed to the Ce $3 \mathrm{~d}_{5 / 2}$ contributions. The peaks at $899.2,900.7,904.0,907.3$, and $916.5 \mathrm{eV}$, corresponding to $\mathrm{u} 0, \mathrm{u}, \mathrm{u}^{\prime}, \mathrm{u}$ ', and $\mathrm{u}^{\prime \prime}$, respectively, are derived from the Ce $3 \mathrm{~d}_{3 / 2}$ contributions. Among these Ce $3 \mathrm{~d}$ peaks, $\mathrm{u}_{0}, \mathrm{u}^{\prime}$, and $\mathrm{v}_{0}, \mathrm{v}^{\prime}$, can be ascribed to the $\mathrm{Ce}^{3+} 3 \mathrm{~d}_{3 / 2}$ and $\mathrm{Ce}^{3+} 3 \mathrm{~d}_{5 / 2}$. While the peaks labeled as u, u", u' "' and v, v", v" "' are assigned to $\mathrm{Ce}^{4+} 3 \mathrm{~d}_{3 / 2}$ and $\mathrm{Ce}^{4+} 3 \mathrm{~d}_{5 / 2}$, respectively. ${ }^{[38,39]}$ It can be seen that more $\mathrm{Ce}^{3+}$ species are detected in all the Bi-doped specimens compared with the Bi-free $\mathrm{CeO}_{2}$. $3 \mathrm{DOM}-\mathrm{Ce}_{0.8} \mathrm{Bi}_{0.2} \mathrm{O}_{2-\delta}$ exhibits the highest ratio of $\mathrm{Ce}^{3+}$ to total $\mathrm{Ce}(16.5 \%)$ among these specimens. 

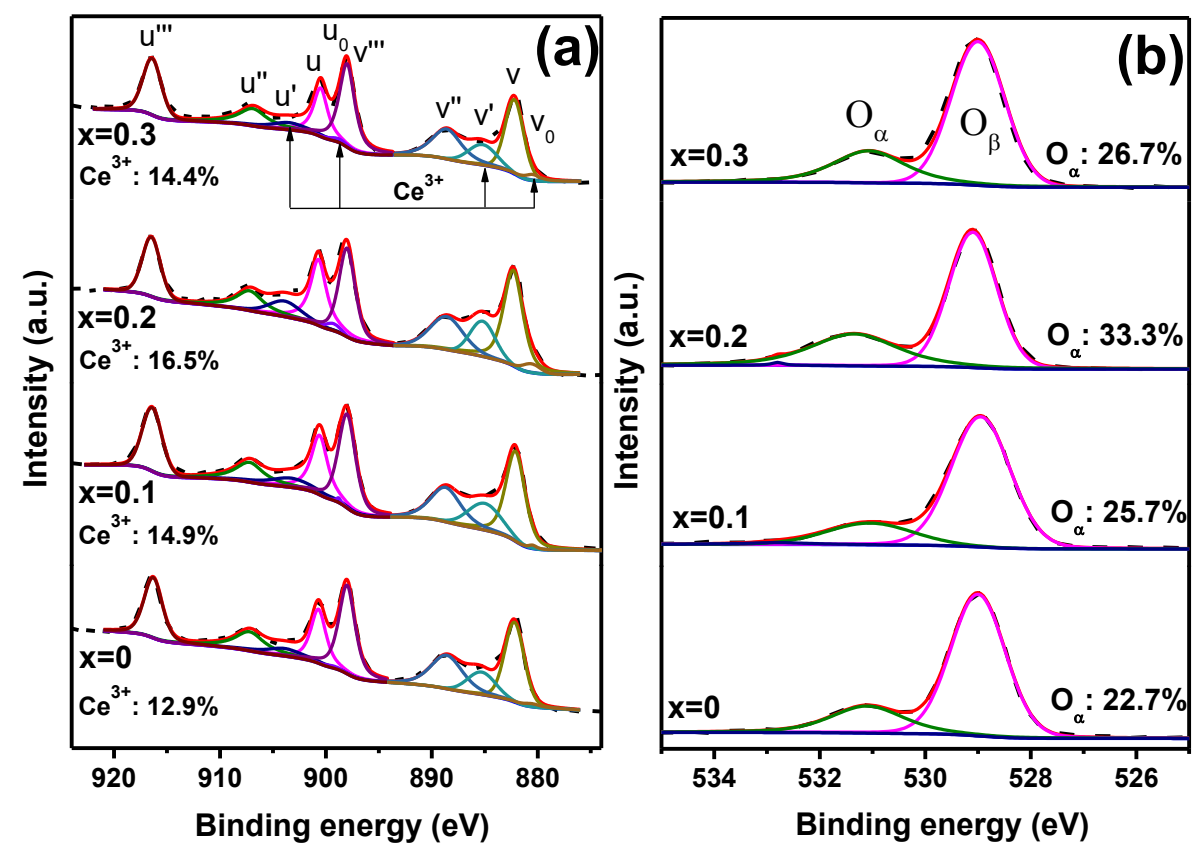

Figure 4. (a) $\mathrm{Ce} 3 \mathrm{~d}$ and (b) $\mathrm{O} 1 \mathrm{~s}$ XPS spectra of $3 \mathrm{DOM}-\mathrm{Ce}_{1-\mathrm{x}} \mathrm{Bi}_{\mathrm{x}} \mathrm{O}_{2-\delta}$ with $\mathrm{x}$ from 0 to 0.3 .

The O 1s XPS was employed to study the chemical states of oxygen in the surface regions of 3DOM-Ce ${ }_{1-\mathrm{x}} \mathrm{Bi}_{\mathrm{x}} \mathrm{O}_{2-\delta}$. As shown in Figure 4b, the peaks centred at 529.0-529.1 eV can be attributed to the lattice $\mathrm{O}^{2-}\left(\right.$ denoted as $\left.\mathrm{O}_{\beta}\right)$, and the peaks centred at 531.2-531.4 eV can be assigned to the chemisorbed oxygen species (denoted as $\mathrm{O}_{\alpha}$ ), such as $\mathrm{O}_{2}{ }^{2-}$ and $\mathrm{O}_{2}{ }^{-} \cdot{ }^{[40]}$ The weak peaks at $\sim 533 \mathrm{eV}$ can be attributed to the absorbed water. ${ }^{[41]}$ The ratio of $\mathrm{O}_{\alpha} /\left(\mathrm{O}_{\alpha}+\mathrm{O}_{\beta}\right)$ represents the oxygen activation capacity of the specimens, which is normally related with their amount of oxygen vacancies. It can be found that $3 \mathrm{DOM}-\mathrm{Ce}_{0.8} \mathrm{Bi}_{0.2} \mathrm{O}_{2-\delta}$ exhibits the highest amount of $\mathrm{O}_{\alpha}$, which is well consistent with the results of Ce $3 \mathrm{~d}$ XPS.

\subsection{Characterization of $\mathrm{Pt} / 3 \mathrm{DOM}-\mathrm{Ce}_{1-x} \mathrm{Bi}_{x} \mathrm{O}_{2-\delta}$ catalysts.}

After deposition of Pt nanoparticles, the inverse opal morphology of the $3 \mathrm{DOM}-\mathrm{Ce}_{1-\mathrm{x}} \mathrm{Bi}_{\mathrm{x}} \mathrm{O}_{2-\delta}$ particles was unchanged as seen in TEM image of $\mathrm{Pt} / 3 \mathrm{DOM}-\mathrm{Ce}_{0.8} \mathrm{Bi}_{0.2} \mathrm{O}_{2-\delta}$ (Figure S5). At a higher magnification, Pt nanocrystallites dispersed on the surface of carrier are visible as dark spots in 
TEM images (Figure 5a). The particle size distribution, measured from 130 randomly chosen $\mathrm{Pt}$ nanoparticles, is quite narrow with the average diameter of about $2.1 \mathrm{~nm}$. The HRTEM image of $\mathrm{Pt} / 3 \mathrm{DOM}-\mathrm{Ce}_{0.8} \mathrm{Bi}_{0.2} \mathrm{O}_{2-\delta}$ catalyst in Figure $5 \mathrm{~b}$ shows lattice fringes corresponding to the (111) planes of cubic $\mathrm{CeO}_{2}$ and Pt crystals. It is noticed that the oxide wall is polycrystalline, constructed with $\mathrm{Bi}$-doped $\mathrm{CeO}_{2}$ nanocrystals, which is consistent with the observation of the wide XRD peaks. The XRD patterns of these Pt/3DOM-Ce ${ }_{1-x} \mathrm{Bi}_{\mathrm{x}} \mathrm{O}_{2-\delta}$ catalysts are shown in Figure S6. All the diffraction peaks derived from $\mathrm{CeO}_{2}$-like face-centered cubic unit cell were still distinct after the deposition of Pt nanoparticles. No diffraction peaks derived from Pt particles can be observed because of their nanoscale particle sizes.
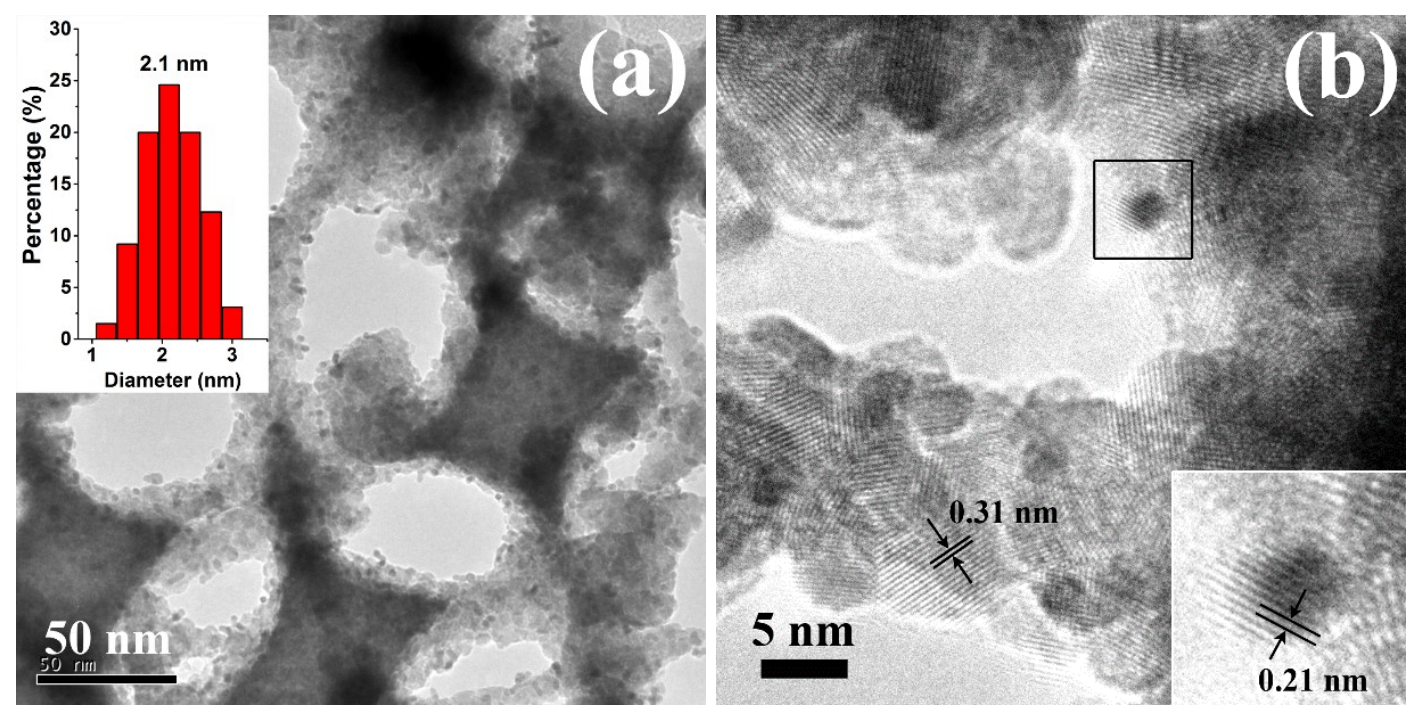

Figure 5. (a) TEM and (b) HRTEM images of $\mathrm{Pt} / 3 \mathrm{DOM}-\mathrm{Ce}_{0.8} \mathrm{Bi}_{0.2} \mathrm{O}_{2-\delta}$ catalyst. The inset in (a) is Pt particle size distribution and the inset in (b) is an enlarged image of the Pt particle marked by a square. The measured d-spacings of 0.21 and $0.31 \mathrm{~nm}$ correspond to the (111) planes in Pt and $3 \mathrm{DOM}-\mathrm{Ce}_{0.8} \mathrm{Bi}_{0.2} \mathrm{O}_{2-\delta}$, respectively. 
The obtained $\mathrm{Pt} / 3 \mathrm{DOM}-\mathrm{Ce}_{1-\mathrm{x}} \mathrm{Bi}_{\mathrm{x}} \mathrm{O}_{2-\delta}$ catalysts were investigated by XPS to reveal electron transfer from Pt to carrier. As seen in Figure 6a, the proportion of $\mathrm{Ce}^{3+}$ in $\mathrm{Pt} / 3 \mathrm{DOM}-\mathrm{Ce}_{1-\mathrm{x}} \mathrm{Bi}_{\mathrm{x}} \mathrm{O}_{2-\delta}$ significantly increases compared with $3 \mathrm{DOM}-\mathrm{Ce}_{1-\mathrm{x}} \mathrm{Bi}_{\mathrm{x}} \mathrm{O}_{2-\delta}$, which means that the $\mathrm{Ce}^{4+}$ ions are further reduced to $\mathrm{Ce}^{3+}$ with the deposition of Pt. Figure $6 \mathrm{~b}$ shows the $\mathrm{Pt} 4 \mathrm{f}$ spectra from $\mathrm{Pt} / 3 \mathrm{DOM}$ $\mathrm{Ce}_{1-\mathrm{x}} \mathrm{Bi}_{\mathrm{x}} \mathrm{O}_{2-\delta}$. The deconvoluted peaks with binding energies of 70.6 70.7 and 73.9 74.0 eV can be attributed to $\mathrm{Pt} 4 \mathrm{f}_{7 / 2}$ and $\mathrm{Pt} 4 \mathrm{f}_{5 / 2}$ of $\mathrm{Pt}^{0}$, respectively. The peaks assigned to $\mathrm{Pt}^{2+}$ appear at 71.8 and $75.2 \mathrm{eV}$. It can be clearly observed that $\mathrm{Pt}$ mainly exists as $\mathrm{Pt}^{0}$ in these samples. But about 26.9-34.3\% of $\mathrm{Pt}$ are oxidized to $\mathrm{Pt}^{2+}$. Taking into account the further reduction of $\mathrm{Ce}^{4+}$ and the partial oxidation of $\mathrm{Pt}$ in $\mathrm{Pt} / 3 \mathrm{DOM}-\mathrm{Ce}_{1-\mathrm{x}} \mathrm{Bi}_{\mathrm{x}} \mathrm{O}_{2-\delta}$ catalysts, the charge transfer from $\mathrm{Pt}$ to $3 \mathrm{DOM}-$ $\mathrm{Ce}_{1-\mathrm{x}} \mathrm{Bi}_{\mathrm{x}} \mathrm{O}_{2-\delta}$ can be confirmed. In addition, from the $\mathrm{Bi}$ 4f XPS spectra of $3 \mathrm{DOM}-\mathrm{Ce}_{0.8} \mathrm{Bi}_{0.2} \mathrm{O}_{2-\delta}$ and $\mathrm{Pt} / 3 \mathrm{DOM}-\mathrm{Ce}_{0.8} \mathrm{Bi}_{0.2} \mathrm{O}_{2-\delta}$ (Figure $\mathrm{S} 7$ ), it can be seen that the $\mathrm{Bi}$ cations are in the $\mathrm{Bi}^{3+}$ state.
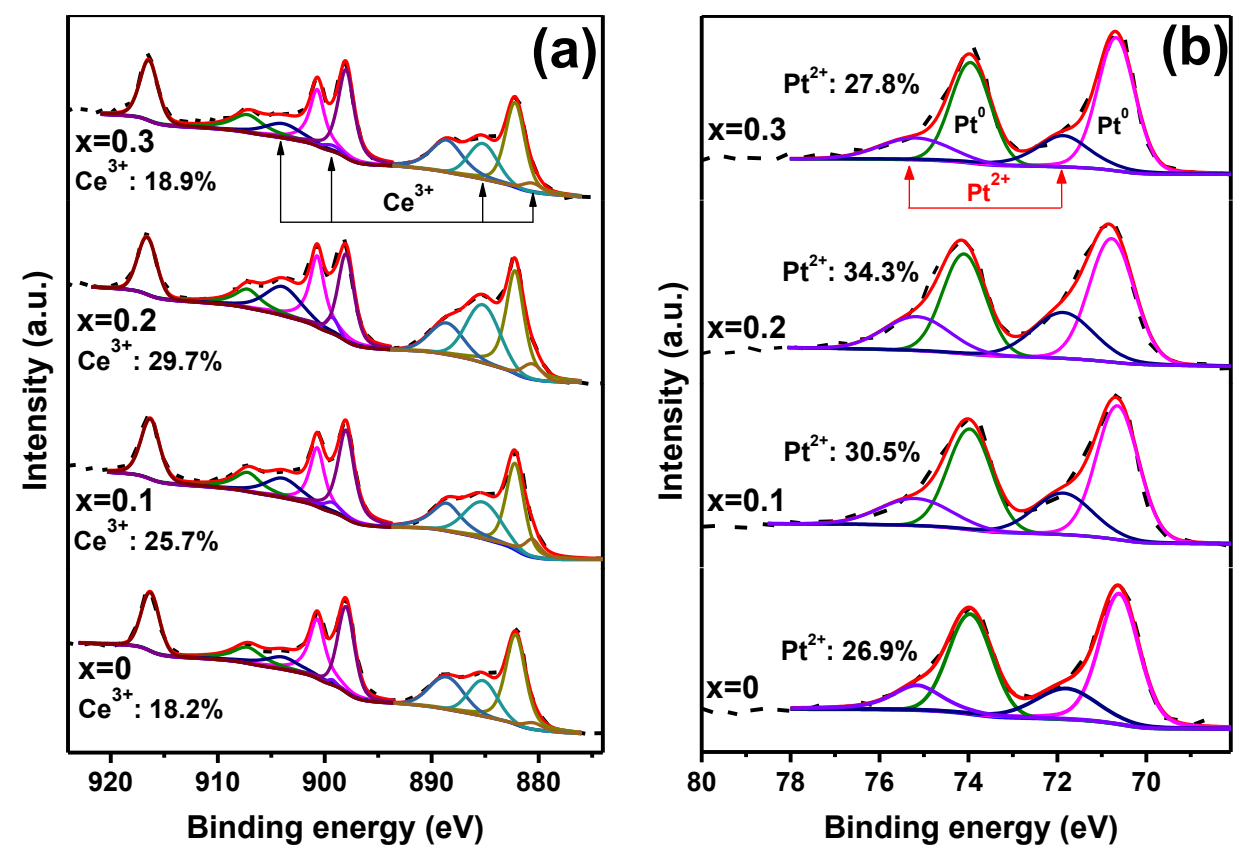

Figure 6. (a) $\mathrm{Ce} 3 \mathrm{~d}$ and (b) $\mathrm{Pt} 4 \mathrm{f} \mathrm{XPS}$ spectra of the $\mathrm{Pt} / 3 \mathrm{DOM}-\mathrm{Ce}_{1-\mathrm{x}} \mathrm{Bi}_{\mathrm{x}} \mathrm{O}_{2-\delta}$ with $\mathrm{x}$ from 0 to 0.3 . 
The percentages of $\mathrm{Ce}^{3+}$ in $3 \mathrm{DOM}-\mathrm{Ce}_{1-\mathrm{x}} \mathrm{Bi}_{\mathrm{x}} \mathrm{O}_{2-\delta}$ before and after the deposition of $\mathrm{Pt}$, and the relative abundances of $\mathrm{Pt}^{2+}$ in $\mathrm{Pt} / 3 \mathrm{DOM}-\mathrm{Ce}_{1-\mathrm{x}} \mathrm{Bi}_{\mathrm{x}} \mathrm{O}_{2-\delta}$ catalysts are listed in Table 1. It is interesting to see that $\mathrm{Pt} / 3 \mathrm{DOM}-\mathrm{Ce}_{0.8} \mathrm{Bi}_{0.2} \mathrm{O}_{2-\delta}$ with the highest amount of $\mathrm{Pt}^{2+}$ exhibits the largest extra increase of $\mathrm{Ce}^{3+}$ induced by the deposition of Pt, suggesting the largest amount of charge transfer from Pt to carrier, in spite of the highest amount of $\mathrm{Ce}^{3+}$ also exists in this catalyst. This observation is of great interest, since we normally think that the existence of $\mathrm{Ce}^{3+}$ would imply that charge transfer from Pt to carrier is inhibited. ${ }^{[1,42]}$

Table 1. The concentrations (\%) of $\mathrm{Ce}^{3+}$ and $\mathrm{Pt}^{2+}$ cations in the surface region of $3 \mathrm{DOM}-\mathrm{Ce}_{1-}$ ${ }_{x} \mathrm{Bi}_{\mathrm{x}} \mathrm{O}_{2-\delta}$ and $\mathrm{Pt} / 3 \mathrm{DOM}-\mathrm{Ce}_{1-\mathrm{x}} \mathrm{Bi}_{\mathrm{x}} \mathrm{O}_{2-\delta}$ detected by XPS. (A) Before and (B) after deposition of Pt.

\begin{tabular}{|c|c|c|c|}
\hline \multirow{2}{*}{ Sample } & \multicolumn{2}{|c|}{$\mathrm{Ce}^{3+} / \mathrm{Ce}(\%)$} & \multirow{2}{*}{$\mathrm{Pt}^{2+} / \mathrm{Pt}(\%$} \\
\hline & (A) & (B) & \\
\hline $3 \mathrm{DOM}-\mathrm{CeO}_{2}$ & 12.9 & 18.2 & 26.9 \\
\hline 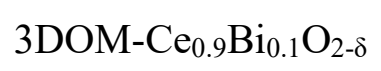 & 14.9 & 25.7 & 30.5 \\
\hline $3 \mathrm{DOM}-\mathrm{Ce}_{0.8} \mathrm{Bi}_{0.2} \mathrm{O}_{2-\delta}$ & 16.5 & 29.7 & 34.3 \\
\hline $3 \mathrm{DOM}-\mathrm{Ce}_{0.7} \mathrm{Bi}_{0.3} \mathrm{O}_{2-\delta}$ & 14.4 & 18.9 & 27.8 \\
\hline
\end{tabular}

\subsection{Effect of Bi-doping on structural properties.}

The appearance of the maximum concentrations of $\mathrm{Ce}^{3+}$ and $\mathrm{Pt}^{2+}$ cations in the $20 \%$ Bi-doped sample indicates that the doping effect on the electronic structure of $\mathrm{CeO}_{2}$ is not monotonous. Although there are several differently coordinated oxygen sites on the crystal surface, such as M$\mathrm{O}-\mathrm{M}, \mathrm{M}-\mathrm{O}-\mathrm{M}_{2}$, and $\mathrm{M}_{2}-\mathrm{O}-\mathrm{M}_{2}(\mathrm{M}=\mathrm{Ce}$ or $\mathrm{Bi})$, to simplify the discussion, we only use the four coordinated oxygen sites as an example in our elucidation of the Bi-doping effect. When an octa- 
coordinated $\mathrm{Ce}^{4+}$ is replaced by a hexa-coordinated $\mathrm{Bi}^{3+}$, two oxygen vacancies will be generated around this $\mathrm{Bi}^{3+}$, forming a cluster of $(\mathrm{Ce}-)_{3} \square-\mathrm{Bi}-\square(-\mathrm{Ce})_{3}$, as shown in Figure $\mathrm{S} 8 \mathrm{a}$. Around the oxygen vacancy, $\mathrm{Bi}^{3+}$ maintains its original oxidation state and $\mathrm{Ce}^{4+}$ would be reduced to $\mathrm{Ce}^{3+}$, forming a cluster of $\mathrm{Bi}^{3+}-\square\left(-\mathrm{Ce}^{3+}\right)_{3}$. The actual oxidation state of a cerium cation depends on its total coordination number of oxygen. It is obvious that the concentration of $\mathrm{Ce}^{3+}$ would be increased with the Bi-doping until formation of stable Bi- $\square-\mathrm{Bi}$ or tetrahedral (Bi-) $)_{2} \square(-\mathrm{Bi})_{2}$ clusters.

When the Bi-doping level is low, all the $\mathrm{Bi}^{3+}$ cations are separated by $\mathrm{Ce}$. In other words, no Bi-O-Bi or Bi- $\square-\mathrm{Bi}$ connection forms. The shortest possible distance between two Bi cations is the same as the fluorite unit cell parameter. The theoretical maximum Bi substitution in such a structure is $25 \%$ according to the ordered model shown in Figure S8b. In the range of Bi-doping below $25 \%$, including $\mathrm{Ce}_{0.9} \mathrm{Bi}_{0.1} \mathrm{O}_{2-\delta}$ and $\mathrm{Ce}_{0.8} \mathrm{Bi}_{0.2} \mathrm{O}_{2-\delta}$, part of $\mathrm{Bi}^{3+}$ cations replace six coordinated $\mathrm{Ce}^{3+}$ without breaking the neutrality and rest of $\mathrm{Bi}^{3+}$ cations replace eight coordinated $\mathrm{Ce}^{4+}$ plus two associated $\mathrm{O}^{2-}$, leading to breaking the local charge balance. To meet the requirement of neutrality at the $\mathrm{Bi}-\square(-\mathrm{Ce})_{3}$ sites, some $\mathrm{Ce}^{4+}$ will be reduced to $\mathrm{Ce}^{3+}$. Consequently, with the Bidoping, not only the number of oxygen vacancies, but also the number of $\mathrm{Ce}^{3+}$ would increase.

When the content of $\mathrm{Bi}^{3+}$ is further increased to $30 \%$, two or more $\mathrm{Bi}^{3+}$ would link to the same oxygen vacancy, forming $\mathrm{Bi}-\square-\mathrm{Bi}$ and even larger Bi-rich clusters. This so called 'like with like' phenomenon has been often found in fluorite-type solid solutions. ${ }^{[43]}$ The amount of asymmetrical $\mathrm{Bi}-\square(-\mathrm{Ce})_{3}$ sites would decrease, while a decrease of the concentration of holes in the $\mathrm{Pt}$ nanoparticles was observed.

Compared with the symmetrical (Ce-) $)_{2} \square(-\mathrm{Ce})_{2}$ sites, the asymmetrical Bi- $\square(-\mathrm{Ce})_{3}$ sites would easily gain oxygen atoms to form $\mathrm{Bi}-\mathrm{O}(-\mathrm{Ce})_{3}$, and easily release oxygen anions to return to $\mathrm{Bi}-\square(-$ Ce) $)_{3}$. Simultaneously, the sites receive electrons from Pt to replenish the lost electrons during the 
reduction of oxygen. Therefore, $\mathrm{Pt} / 3 \mathrm{DOM}-\mathrm{Ce}_{0.8} \mathrm{Bi}_{0.2} \mathrm{O}_{2-\delta}$ with the largest amount of $\mathrm{Bi}-\square(-\mathrm{Ce})_{3}$ sites exhibits the highest ability of electron transfer from Pt.

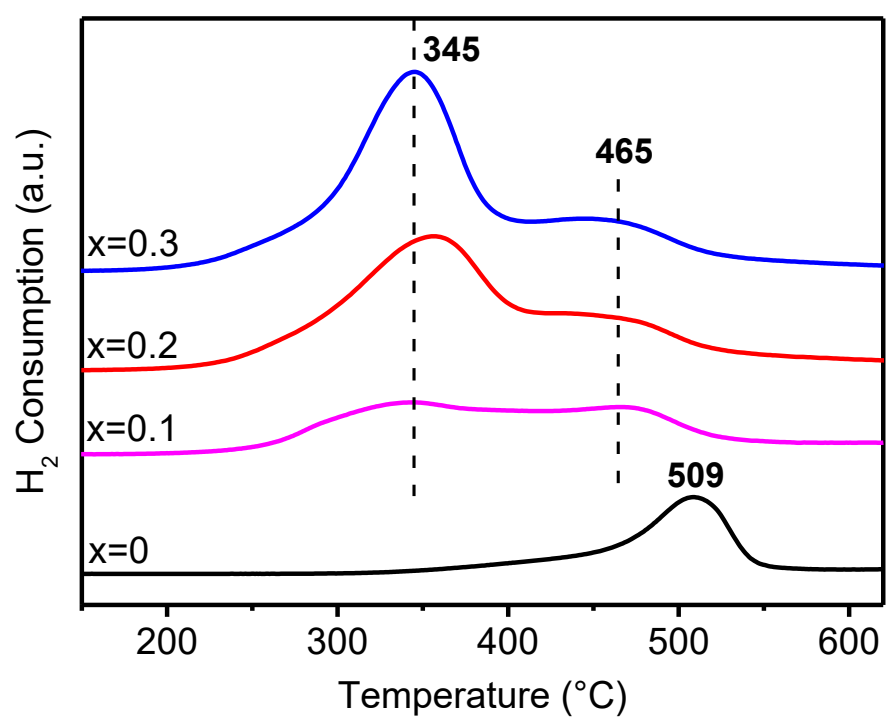

Figure 7. The $\mathrm{H}_{2}-\mathrm{TPR}$ results of the $3 \mathrm{DOM}-\mathrm{Ce}_{1-\mathrm{x}} \mathrm{Bi}_{\mathrm{x}} \mathrm{O}_{2-\delta}$ specimens with $\mathrm{x}$ from 0 to 0.3 .

The difference between the oxygen sites in $\mathrm{Bi}$-doped $\mathrm{CeO}_{2}$, e.g. $\mathrm{Bi}-\square(-\mathrm{Ce})_{3}$ and the sites in pure $\mathrm{CeO}_{2}$, e.g. (Ce- $)_{2} \square(-\mathrm{Ce})_{2}$ can be experimentally confirmed by the $\mathrm{H}_{2}-\mathrm{TPR}$ of $3 \mathrm{DOM}-\mathrm{Ce}_{1}$ ${ }_{x} \mathrm{Bi}_{\mathrm{x}} \mathrm{O}_{2-\delta}$, as shown in Figure 7. With the $\mathrm{Bi}^{3+}$-doping, the reduction peaks of $3 \mathrm{DOM}-\mathrm{Ce}_{1-\mathrm{x}} \mathrm{Bi}_{\mathrm{x}} \mathrm{O}_{2-\delta}$ are shifted from $509{ }^{\circ} \mathrm{C}$ to at least two lower-temperature regions centered at ca. (I) $345{ }^{\circ} \mathrm{C}$ and (II) $465{ }^{\circ} \mathrm{C}$, indicating the formation of new types of redox sites and the interaction between $\mathrm{CeO}_{2}$ and the dopant ions. The reduction peaks located at $345^{\circ} \mathrm{C}$ should be attributed to oxygen removal from the redox sites associated with $\mathrm{Bi}^{3+}$, including $\mathrm{Bi}-\mathrm{O}(-\mathrm{Ce})_{3}$ clusters. The reduction peaks centered at $465^{\circ} \mathrm{C}$ can be derived from the redox sites associated with $\mathrm{Ce}^{4+}$, which moved from $509{ }^{\circ} \mathrm{C}$ to lower-temperature region because of the interaction between $\mathrm{Ce}^{4+}$ and the doped $\mathrm{Bi}^{3+}$ ions. The related hydrogen consumption data have been listed in Table S2. The results show 
unambiguously that the Bi-doping not only decreases the reduction temperature, but also increases the $\mathrm{H}_{2}$ consumption in comparison with pure $\mathrm{CeO}_{2}$, suggesting a better redox property.

\subsection{DFT calculation of the asymmetrical oxygen vacancy sites.}

In order to further prove the excellent oxygen adsorption ability and oxygen release ability of these asymmetrical $\mathrm{Bi}-\square(-\mathrm{Ce})_{3}$ sites compared with symmetrical $(\mathrm{Ce}-)_{2} \square(-\mathrm{Ce})_{2}$ sites, the adsorption energy of oxygen $\left(E_{a d s}\right)$ and the formation energy of oxygen vacancy $\left[E_{f}(O v)\right]$ of these sites were calculated. On the surface of $\mathrm{CeO}_{2}(111)$, the coordination number of oxygen in these oxygen vacancy sites is three. Thus, $\mathrm{Bi}-\square(-\mathrm{Ce})_{2}$ and $\mathrm{Ce}-\square(-\mathrm{Ce})_{2}$ should be the main existence forms of these oxygen vacancy sites.
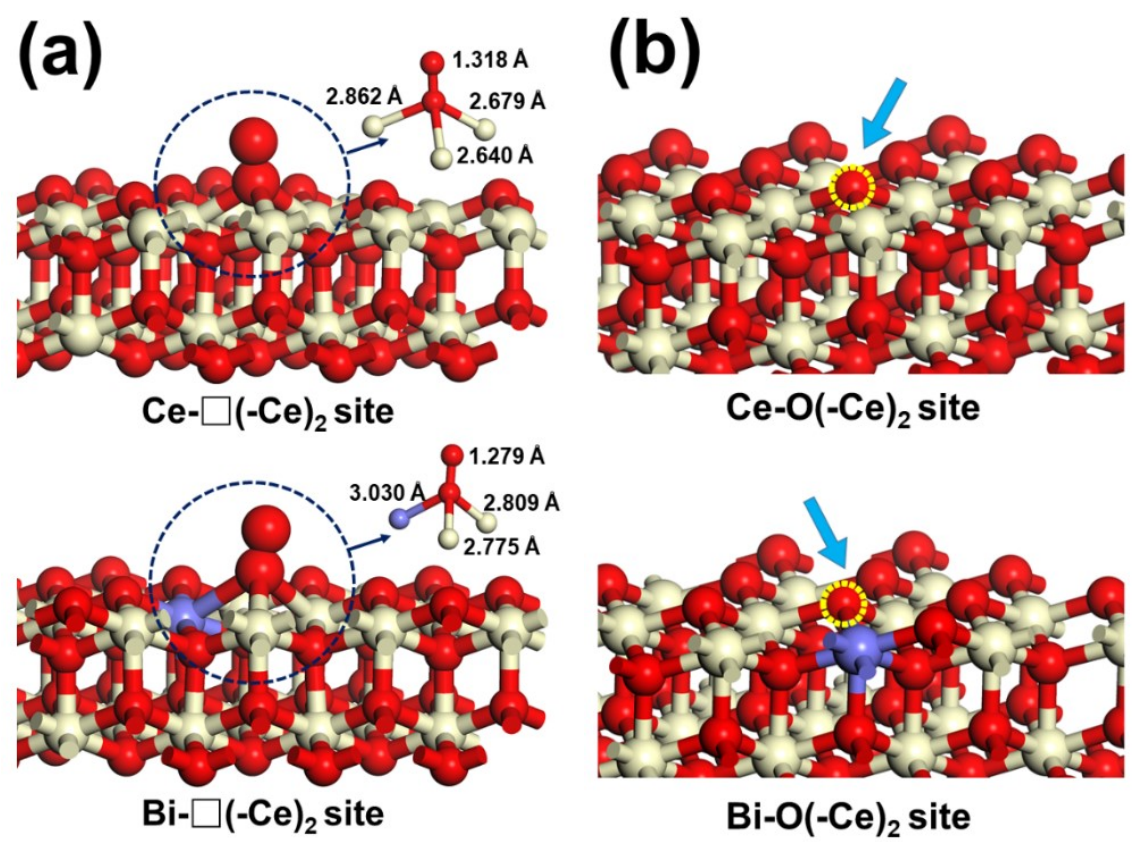

$\mathrm{Bi}-\mathrm{O}(-\mathrm{Ce})_{2}$ site

Figure 8. (a) The geometries of $\mathrm{O}_{2}$ adsorbed on $\mathrm{Bi}-\square(-\mathrm{Ce})_{2}$ and $\mathrm{Ce}-\square(-\mathrm{Ce})_{2}$ sites. The relevant bond lengths are marked. (b) DFT-calculated structure for $\mathrm{E}_{\mathrm{f}}(\mathrm{Ov})$ on $\mathrm{Bi}-\mathrm{O}(-\mathrm{Ce})_{2}$ and $\mathrm{Ce}-\mathrm{O}(-\mathrm{Ce})_{2}$ sites. The $\mathrm{Ce}^{4+}, \mathrm{O}, \mathrm{Bi}$ are colored by grey, red and purple, respectively. The circled $\mathrm{O}$ atoms in Figure $8(b)$ are the oxygen to be released. 
The $E_{a d s}$ of these sites were calculated as $E_{a d s}=E_{A / S}-\left(E_{A}+E_{S}\right)$, where $E_{A}, E_{S}$ and $E_{A / S}$ represent for the energy of adsorbed species, the energy of free substrate and total energy of adsorbate-substrate system, respectively. The geometrical structures of $\mathrm{O}_{2}$ adsorbed into asymmetrical Bi- $\square(-\mathrm{Ce})_{2}$ or symmetrical Ce- $\square(-\mathrm{Ce})_{2}$ sites are shown in Figure 8(a), the related $\mathrm{E}_{\text {ads }}$ data are listed in Table 2. The $\mathrm{O}_{2}$ molecule was adsorbed at the hollow site of $\mathrm{Bi}-\square(-\mathrm{Ce})_{2}$ or Ce$\square(-\mathrm{Ce})_{2}$. It can be found that the adsorption of $\mathrm{O}_{2}$ on these oxygen vacancy sites is an exothermic process. Although a lower $\mathrm{E}_{\mathrm{ads}}$ of $\mathrm{O}_{2}$ on the $\mathrm{Ce}-\square-(\mathrm{Ce})_{2}$ sites is obtained, the $\mathrm{E}_{\text {ads }}$ of $\mathrm{O}_{2}$ on the $\mathrm{Bi}$ $\square-(\mathrm{Ce})_{2}$ sites is also very low $(-4.61 \mathrm{eV})$, indicating that $\mathrm{O}_{2}$ is easily adsorbed on both oxygen vacancy sites. On the other hand, the bond length of adsorbed oxygen molecule on the Bi-O-(Ce) 2 sites is relatively shorter and the $\mathrm{Bi}-\mathrm{O}$ and $\mathrm{Ce}-\mathrm{O}$ bond lengths are significantly longer than those in the Ce-O- $(\mathrm{Ce})_{2}$ sites, as seen in Figure 8(a). It implies that the oxygen molecules on the Bi-O$(\mathrm{Ce})_{2}$ sites are less stable and tend to leave as activated pieces. The charge imbalance at the $\mathrm{Bi}$ cations introduced by an extra Bi-O bond further increases the instability of the oxygen.

Table 2. The calculated adsorption energy of oxygen and the formation energy of oxygen vacancy on different sites of $\mathrm{CeO}_{2}(111)$ surface

\begin{tabular}{lll}
\hline Energy & $\mathrm{Bi}-\square(-\mathrm{Ce})_{2}$ & $\mathrm{Ce}-\square(-\mathrm{Ce})_{2}$ \\
\hline $\mathrm{E}_{\text {ads }}(\mathrm{eV})$ & -4.61 & -6.83 \\
$\mathrm{E}_{\mathrm{f}}(\mathrm{Ov})(\mathrm{eV})$ & 0.70 & 1.67 \\
\hline
\end{tabular}


The $\mathrm{E}_{\mathrm{f}}(\mathrm{Ov})$ of these sites (Figure $\left.8 \mathrm{~b}\right)$ was calculated through the formula of $\mathrm{E}_{\mathrm{f}}(\mathrm{Ov})=\mathrm{E}_{\mathrm{def}}-$ $E_{\text {free }}+\frac{1}{2} E_{\mathrm{O}_{2}}$, in which $E_{\text {def, }}, E_{\text {free }}$ and $E_{\mathrm{O}_{2}}$ are the energies of the defective structure with an oxygen vacancy, the perfect system and the free molecular oxygen, respectively. ${ }^{[44]}$ The obtained $\mathrm{E}_{\mathrm{f}}(\mathrm{Ov})$ results are also listed in Table 2 . It can be found that the $\mathrm{E}_{\mathrm{f}}(\mathrm{Ov})$ of $\mathrm{Ce}-\mathrm{O}(-\mathrm{Ce})_{2}$ site is $1.67 \mathrm{eV}$, which is significantly higher than that of asymmetrical $\mathrm{Bi}-\mathrm{O}(-\mathrm{Ce})_{2}$ site $(0.70 \mathrm{eV})$. This result indicates that the oxygen atoms in the asymmetrical $\mathrm{Bi}-\mathrm{O}(-\mathrm{Ce})_{2}$ sites are more active and easily to be released from these sites. The DFT calculation results further prove the notably enhanced redox property of these asymmetrical oxygen vacancy sites compared with symmetrical sites in pure $\mathrm{CeO}_{2-\delta}$.

\subsection{Effect of Bi-doping on catalytic performance.}

The influence of Bi-doping in $\mathrm{Pt} / 3 \mathrm{DOM}-\mathrm{Ce}_{1-\mathrm{x}} \mathrm{Bi}_{\mathrm{x}} \mathrm{O}_{2-\delta}$ on catalytic performance was evaluated in the aerobic oxidation of HMF toward FDCA at ambient pressure (Figure 9). The final results after $10 \mathrm{~h}$ reaction over these catalysts and the calculated turnover frequency (TOF) values are listed in Table 3.
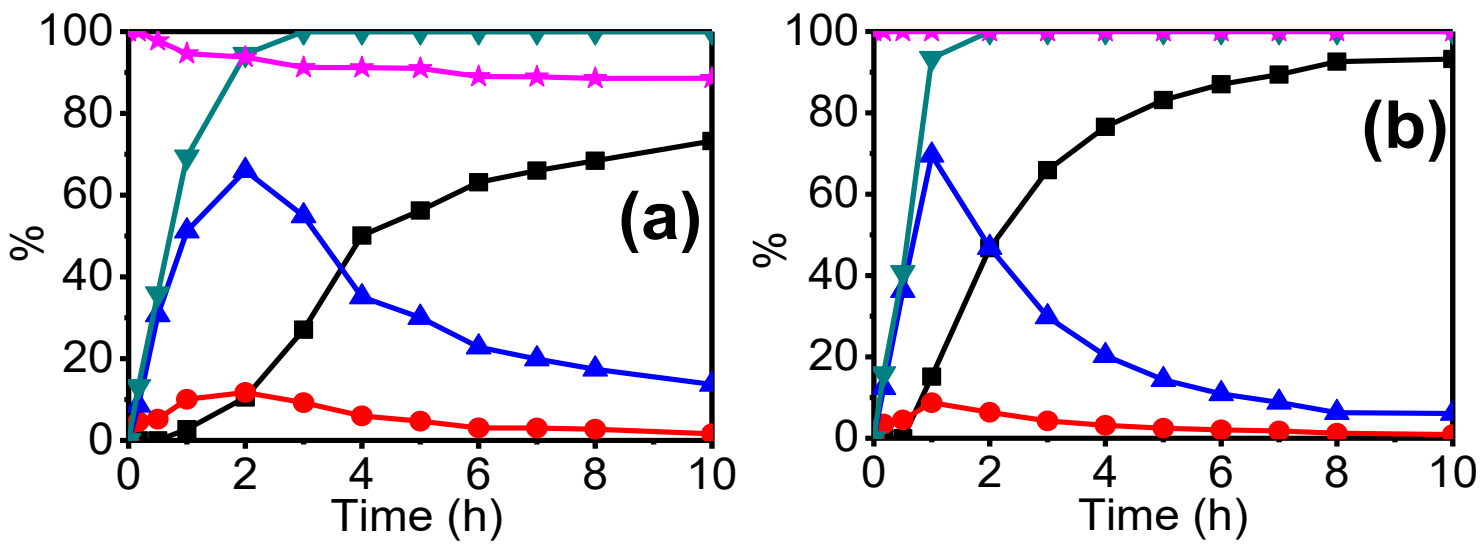

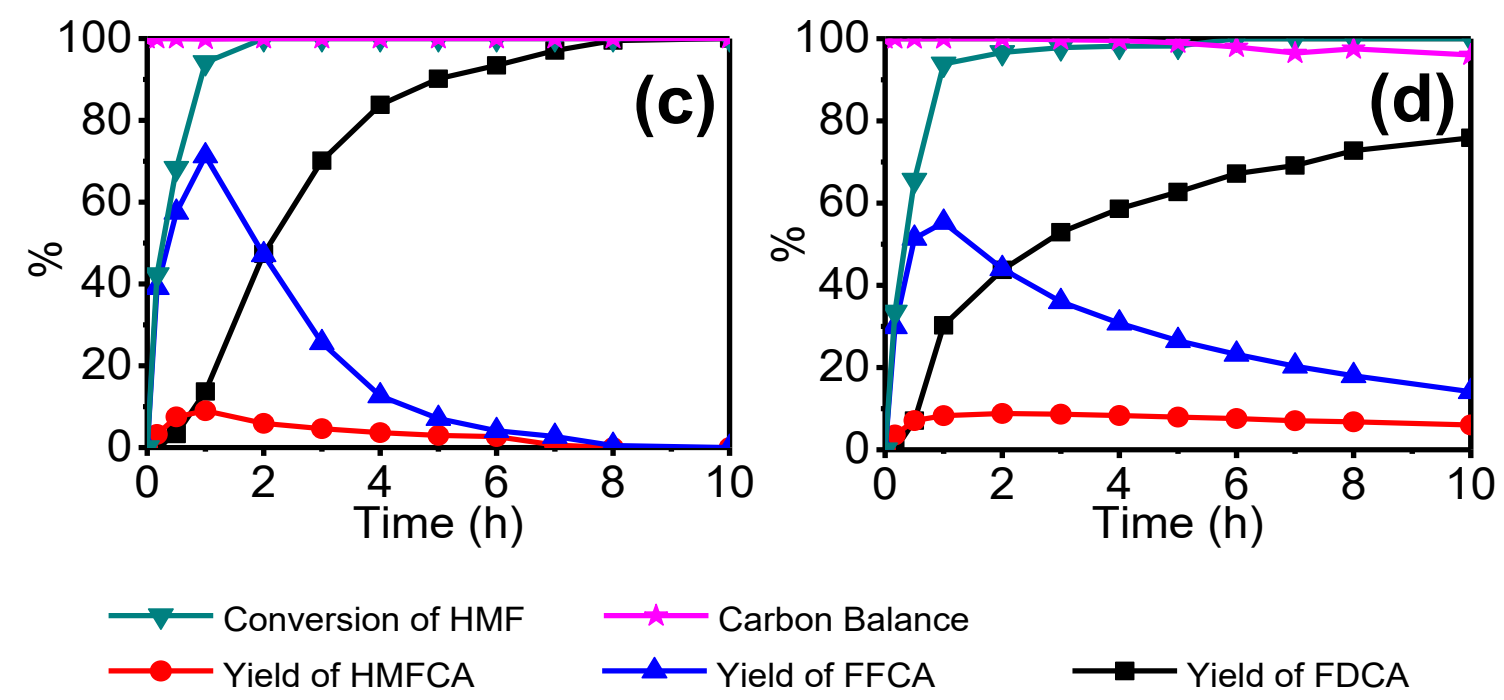

Figure 9. Reaction profiles for the oxidation of $\mathrm{HMF}$ on $\mathrm{Pt} / 3 \mathrm{DOM}-\mathrm{Ce}_{1-\mathrm{x}} \mathrm{Bi}_{\mathrm{x}} \mathrm{O}_{2-\delta}$ catalysts, when (a) $\mathrm{x}=0$, (b) $\mathrm{x}=0.1$, (c) $\mathrm{x}=0.2$, (d) $\mathrm{x}=0.3$. Reaction conditions: $n_{\mathrm{HMF}} / n_{\mathrm{Pt}}=100, n_{\mathrm{HMF}} / n_{\mathrm{NaHCO} 3}=$ $0.25,90{ }^{\circ} \mathrm{C}$, with $\mathrm{O}_{2}$ bubbling $\left(70 \mathrm{~mL} \mathrm{~min}^{-1}\right)$.

Table 3. Catalytic performance of $\mathrm{Pt} / 3 \mathrm{DOM}-\mathrm{Ce}_{1-\mathrm{x}} \mathrm{Bi}_{\mathrm{x}} \mathrm{O}_{2-\delta}$ catalysts for the aerobic oxidation of $\mathrm{HMF}^{[\mathrm{a}]}$

\begin{tabular}{|c|c|c|c|c|c|c|c|}
\hline \multirow{2}{*}{ Entry } & \multirow{2}{*}{ Catalyst } & \multirow{2}{*}{$\begin{array}{l}\text { HMF Conv. } \\
(\%)\end{array}$} & \multicolumn{3}{|c|}{ Yield (\%) } & \multirow{2}{*}{$\begin{array}{l}\text { Carbon Balance } \\
(\%)\end{array}$} & \multirow{2}{*}{$\begin{array}{l}\text { TOF value } e^{[b]} \\
\left(\min ^{-1}\right)\end{array}$} \\
\hline & & & FDCA & FFCA & HMFCA & & \\
\hline 1 & $\mathrm{Pt} / 3 \mathrm{DOM}-\mathrm{CeO}_{2}$ & 100 & 73 & 14 & 2 & 89 & 3.24 \\
\hline 2 & $\mathrm{Pt} / 3 \mathrm{DOM}-\mathrm{Ce}_{0.9} \mathrm{Bi}_{0.1} \mathrm{O}_{2-\delta}$ & 100 & 93 & 6 & 1 & $>99$ & 4.24 \\
\hline 3 & $\mathrm{Pt} / 3 \mathrm{DOM}-\mathrm{Ce}_{0.8} \mathrm{Bi}_{0.2} \mathrm{O}_{2-\delta}$ & 100 & $>99$ & 0 & 0 & $>99$ & 9.27 \\
\hline 4 & $\mathrm{Pt} / 3 \mathrm{DOM}-\mathrm{Ce}_{0.7} \mathrm{Bi}_{0.3} \mathrm{O}_{2-\delta}$ & 100 & 76 & 14 & 6 & 96 & 7.00 \\
\hline 5 & $\mathrm{Pt} / 3 \mathrm{DOM}-\mathrm{Ce}_{0.5} \mathrm{Bi}_{0.5} \mathrm{O}_{2-\delta}$ & 100 & 66 & 14 & 5 & 85 & ---- \\
\hline 6 & $3 \mathrm{DOM}-\mathrm{CeO}_{2}$ & 40 & 0 & 0 & 2 & 62 & ---- \\
\hline 7 & 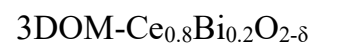 & 50 & 4 & 3 & 2 & 59 & ---- \\
\hline
\end{tabular}

${ }^{[\mathrm{a}]}$ Reaction conditions: $n_{\mathrm{HMF}} / n_{\mathrm{Pt}}=100, n_{\mathrm{HMF}} / n_{\mathrm{NaHCO} 3}=0.25,90{ }^{\circ} \mathrm{C}, 10 \mathrm{~h}, \mathrm{O}_{2}$ bubbling $(70 \mathrm{~mL}$ $\left.\min ^{-1}\right)$.

[b] TOF values were calculated from the results at $10 \mathrm{~min}$ reaction using the equation, ${ }^{[45,46]}$ and 
Pt dispersion was determined by $\mathrm{CO}$ chemisorption.

$\operatorname{TOF}\left(\min ^{-1}\right)=\frac{\operatorname{Conv}_{\mathrm{HMF}}(\%) \times\left(n_{\mathrm{HMF}} / n_{\mathrm{Pt}}\right)}{\text { time }(\min ) \times \mathrm{Pt} \text { dispersion }}$

As shown in Figure 9 and Table 3, all of these $\mathrm{Pt} / 3 \mathrm{DOM}-\mathrm{Ce}_{1-\mathrm{x}} \mathrm{Bi}_{\mathrm{x}} \mathrm{O}_{2-\delta}$ catalysts exhibited good catalytic activity for the aerobic oxidation of HMF. In the first $2 \mathrm{~h}$, FFCA was the main intermediate product in these reaction system, indicating that the conversion from FFCA to FDCA is the rate determining step of the reaction over $\mathrm{Pt} / 3 \mathrm{DOM}-\mathrm{Ce}_{1-\mathrm{x}} \mathrm{Bi}_{\mathrm{x}} \mathrm{O}_{2-\delta}$, which can be clearly observed from the kinetic simulation results according to the reported methods ${ }^{[46,47]}$ based on these reaction data (as shown in Figure S9), and was also found in relevant literatures on Pt-based catalysts $^{[19,48,49]}$. It is very different with $\mathrm{Au}$ or Pd catalyzed reaction ${ }^{[17,18,20,21,22,45]}$, in which the dehydrogenation of hydroxymethyl group of HMFCA to FFCA is the rate determining step. Among these $\mathrm{Pt} / 3 \mathrm{DOM}-\mathrm{Ce}_{1-\mathrm{x}} \mathrm{Bi}_{\mathrm{x}} \mathrm{O}_{2-\delta}$ catalysts, $\mathrm{Pt} / 3 \mathrm{DOM}-\mathrm{CeO}_{2}$ exhibited relatively poor catalytic performance. When $10 \%$ of cerium were replaced by $\mathrm{Bi}^{3+}$, the catalytic behavior of the catalyst was enhanced significantly. The highest yield of FDCA was achieved with $20 \%$ Bi-doping.

When the Bi-doping level increased to $30 \%$, the yield of FDCA decreased to $76 \%$. Further increasing the Bi-doping level to $50 \%$, the obtained $\mathrm{Pt} / 3 \mathrm{DOM}-\mathrm{Ce}_{0.5} \mathrm{Bi}_{0.5} \mathrm{O}_{2-\delta}$ catalyst exhibited the lowest yield of FDCA among these $\mathrm{Pt} / 3 \mathrm{DOM}-\mathrm{Ce}_{1-\mathrm{x}} \mathrm{Bi}_{\mathrm{x}} \mathrm{O}_{2-\delta}$ catalysts (entry 5, Table 3 ). In addition, as shown in Table 3, the carbon balance values for the reactions over $\mathrm{Pt} / 3 \mathrm{DOM}-\mathrm{Ce}_{0.9} \mathrm{Bi}_{0.1} \mathrm{O}_{2-\delta}$ and $\mathrm{Pt} / 3 \mathrm{DOM}-\mathrm{Ce}_{0.8} \mathrm{Bi}_{0.2} \mathrm{O}_{2-\delta}(>99 \%)$ are notably higher than those over $\mathrm{Pt} / 3 \mathrm{DOM}-\mathrm{Ce}_{0.7} \mathrm{Bi}_{0.3} \mathrm{O}_{2-\delta}$ (96\%), Pt/3DOM-CeO 2 (89\%) and $\mathrm{Pt} / 3 \mathrm{DOM}-\mathrm{Ce}_{0.5} \mathrm{Bi}_{0.5} \mathrm{O}_{2-\delta}(85 \%)$, which can be attributed to the faster conversion of intermediate products to relatively stable FDCA over Pt/3DOM-Ce ${ }_{0.9} \mathrm{Bi}_{0.1} \mathrm{O}_{2}$ $\delta$ and $\mathrm{Pt} / 3 \mathrm{DOM}-\mathrm{Ce}_{0.8} \mathrm{Bi}_{0.2} \mathrm{O}_{2-\delta}$. It can be also observed from Table 3, the TOF value of Pt/3DOM$\mathrm{Ce}_{0.8} \mathrm{Bi}_{0.2} \mathrm{O}_{2-\delta}$ reachs up to $9.27 \mathrm{~min}^{-1}$, which is 2.9 times as high as that of $\mathrm{Pt} / 3 \mathrm{DOM}-\mathrm{CeO}_{2}$. 
Compared with ever reported catalysts as listed in Table $\mathrm{S} 3, \mathrm{Pt} / 3 \mathrm{DOM}-\mathrm{Ce}_{0.8} \mathrm{Bi}_{0.2} \mathrm{O}_{2-\delta}$ should be a promising catalyst under mild reaction conditions. Although the same optimized doping level of $\mathrm{Bi}^{3+}$ was found in $\mathrm{Pt} / 3 \mathrm{DOM}-\mathrm{Ce}_{1-\mathrm{x}} \mathrm{Bi}_{\mathrm{x}} \mathrm{O}_{2-\delta}$ catalysts compared with the ever reported literatures, ${ }^{[21,23]}$ an obviously different promoting mechanism of $\mathrm{Pt} / 3 \mathrm{DOM}-\mathrm{Ce}_{1-\mathrm{x}} \mathrm{Bi}_{\mathrm{x}} \mathrm{O}_{2-\delta}$ compared with $\mathrm{Pt} / 3 \mathrm{DOM}-\mathrm{CeO}_{2}$ was proposed in this work. We believe this $\mathrm{Bi}$-doping effect associates closely to the newly created asymmetrical oxygen vacancy site of Bi- $\square(-\mathrm{Ce})_{3}$ as discussed above.

\subsection{Role of the asymmetrical oxygen vacancy site in promoting electron transfer and} catalytic performance

In order to investigate the electronic interaction between the sites of oxygen vacancy and the Pt nanoparticles, a calculation model with a tetrahedral Pt4 cluster adsorbed on $\mathrm{Bi}-\square(-\mathrm{Ce})_{2}, \mathrm{Ce}-\square(-$ $\mathrm{Ce})_{2}$ and $\mathrm{Ce}-\mathrm{O}(-\mathrm{Ce})_{2}$ sites on the surface of $\mathrm{CeO}_{2}(111)$, as described in Figure 10, was employed. The Bader charge analysis was carried out to study the electron density of Pt4 cluster ${ }^{[50,51]}$ and the results are listed in Table 4. Bader valence of Pt atoms adsorbed on Ce-based metal oxide can indicate the directionality and the quantity of electron transfer ${ }^{[52]}$ It can be seen that the Bader valence of Pt atoms on $\mathrm{Bi}-\square(-\mathrm{Ce})_{2}, \mathrm{Ce}-\square(-\mathrm{Ce})_{2}$, and $\mathrm{Ce}-\mathrm{O}(-\mathrm{Ce})_{2}$ decreased by $-0.71|\mathrm{e}|,-0.62|\mathrm{e}|$, and $-0.76|\mathrm{e}|$, respectively. The electro-positivity of Pt4 cluster indicates the electron transfer from Pt4 cluster to the carrier, which is consistent with the results of XPS characterization. Moreover, compared with the symmetrical Ce- $\square(-\mathrm{Ce})_{2}$ sites, Pt4 cluster adsorbed on asymmetrical Bi- $\square(-\mathrm{Ce})_{2}$ sites exhibited larger amount of electron transfer, although the strongest charge transfer took place on Pt4/Ce-O(-Ce) $)_{2}$ sites from Bader charge analysis.

To determine the preferred adsorption site of Pt4 cluster on the surface of $\mathrm{CeO}_{2}(111)$, the adsorption energies are calculated and the results are listed in Table 4. The more negative adsorption energies of Pt4 adsorbed on oxygen vacancy sites compared to $\mathrm{Ce}-\mathrm{O}(-\mathrm{Ce})_{2}$ site 
indicates that Pt nanoparticles are likely to be preferentially adsorbed on the oxygen vacancy sites. From the results of DFT calculation, the conclusion can be deduced that the existence of asymmetrical $\mathrm{Bi}-\square(-\mathrm{Ce})_{3}$ oxygen vacancy sites can effectively stabilize Pt nanoparticles and promote the electron transfer from Pt to carrier.
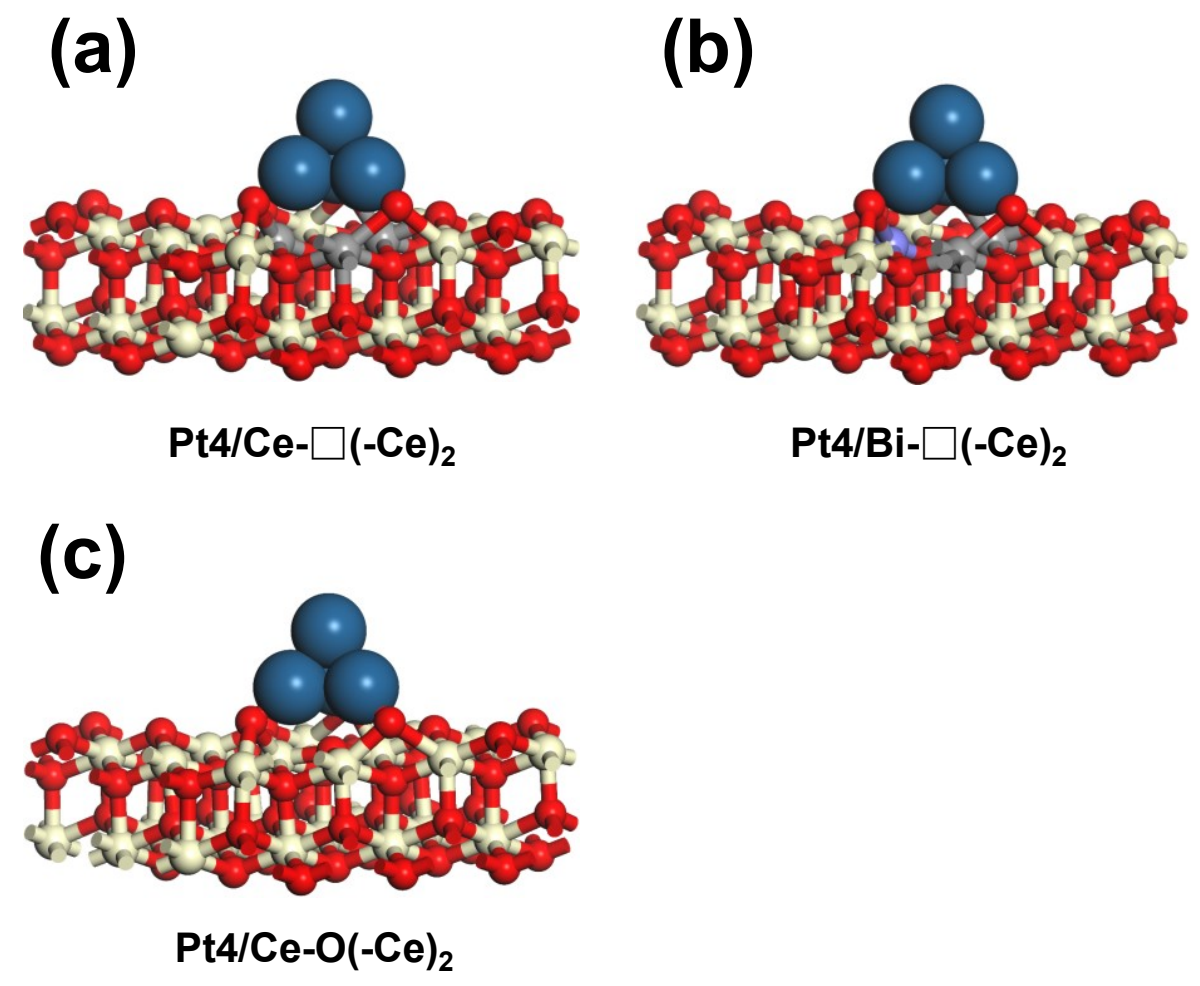

Figure 10. Geometries of (a) Pt4/Ce- $\square(-\mathrm{Ce})_{2}$, (b) Pt4/Bi- $\square(-\mathrm{Ce})_{2}$ and (c) $\mathrm{Pt} 4 / \mathrm{Ce}-\mathrm{O}(-\mathrm{Ce})_{2}$.

Table 4. The Bader charge and adsorption energy of Pt4 cluster on Bi- $\square(-\mathrm{Ce})_{2}, \mathrm{Ce}-\square(-\mathrm{Ce})_{2}$ or $\mathrm{Ce}-\mathrm{O}(-\mathrm{Ce})_{2}$ sites of $\mathrm{CeO}_{2}(111)$ surface.

\begin{tabular}{llll}
\hline & Pt4/Bi- $\square(-\mathrm{Ce})_{2}$ & Pt4/Ce- $\square(-\mathrm{Ce})_{2}$ & $\mathrm{Pt} 4 / \mathrm{Ce}-\mathrm{O}(-\mathrm{Ce})_{2}$ \\
\hline Bader valence $|\mathrm{e}|$ & -0.71 & -0.62 & -0.76 \\
$\mathrm{E}_{\mathrm{ad}}(\mathrm{eV})$ & -7.15 & -7.67 & -4.92 \\
\hline
\end{tabular}


However, the dehydrogenation reactions of HMF on the surface of Pt nanoparticles with the assistance of $\mathrm{OH}^{-}$anions would leave excess electrons on Pt nanoparticles. ${ }^{[3,54]}$ Therefore, a continuous electron transfer from $\mathrm{Pt}$ to carrier may exist on these $\mathrm{Pt} / 3 \mathrm{DOM}-\mathrm{Ce}_{1-\mathrm{x}} \mathrm{Bi}_{\mathrm{x}} \mathrm{O}_{2-\delta}$ catalysts under the aerobic oxidation conditions. It has been known that the oxygen vacancies in $\mathrm{CeO}_{2}$ based materials can be active sites for oxygen activation. The adsorbed $\mathrm{O}_{2}$ can be activated and converted to superoxo- or peroxo- oxygen (i.e. $\mathrm{O}_{2}{ }^{-}$or $\mathrm{O}_{2}{ }^{2-}$ ) as described in eq. (1)-(3). The $\mathrm{O}_{2}{ }^{2-}$ can be dissociated to monatomic $\mathrm{O}^{-}$, and further reduced to lattice oxygen $\left(\mathrm{O}^{2-}\right)$ at these sites. ${ }^{[55]}$ On the other hand, these active oxygen species can leave the crystals, restoring the oxygen vacancies, by reacting with $\mathrm{H}_{2} \mathrm{O}$ to form $\mathrm{H}_{2} \mathrm{O}_{2}$ and $\mathrm{OH}^{-}$(eq. 4). These $\mathrm{O}_{2}$ activation reactions occurred at $\mathrm{CeO}_{2}$ surface can consume a large amount of electrons. Consequently, this process should be the real driving force of continuous electron transfer from Pt to carrier.

$$
\begin{aligned}
& \mathrm{O}_{2}+\mathrm{Ce}^{3+} \rightarrow \mathrm{O}_{2}{ }^{-}+\mathrm{Ce}^{4+} \\
& \mathrm{Ce}^{4+}+\mathrm{e}^{-} \rightarrow \mathrm{Ce}^{3+} \\
& \mathrm{O}_{2}{ }^{-}+\mathrm{e}^{-} \rightarrow \mathrm{O}_{2}{ }^{2-} \\
& \mathrm{O}_{2}{ }^{2-}+2 \mathrm{H}_{2} \mathrm{O} \rightarrow \mathrm{H}_{2} \mathrm{O}_{2}+2 \mathrm{OH}^{-}
\end{aligned}
$$

Following the above discussions, we are now able to propose a mechanism of Bi-doping on the promoting electron transfer and catalytic performance for the aerobic oxidation of HMF, as illustrated in Figure 11. In this schematic, only tetrahedral clusters, Bi-O(-Ce) $)_{3}$ were used to elucidate their role in the catalytic reaction, although they can be three or two coordinated on the crystal surface. 


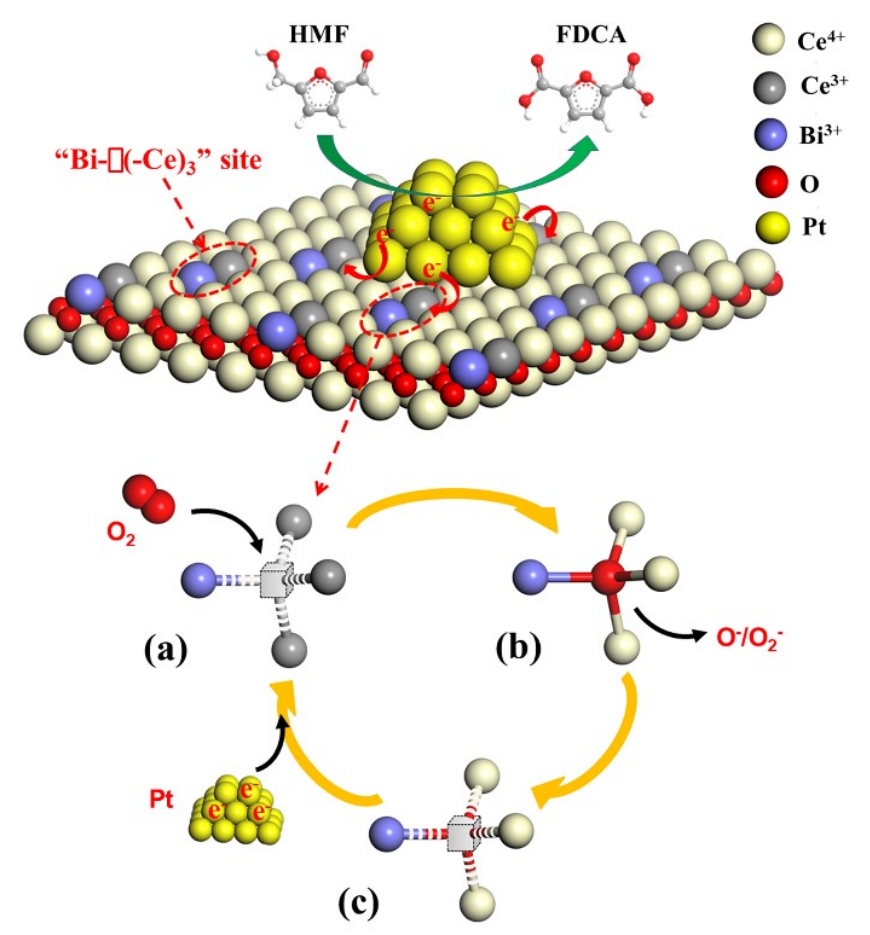

Figure 11. Top: Plausible reaction mechanism of HMF oxidation over Pt/3DOM-Ce ${ }_{1-\mathrm{x}} \mathrm{Bi}_{\mathrm{x}} \mathrm{O}_{2-\delta}$ catalysts. Surface oxygen anions are not shown for a simplicity. Bottom: A schematic drawing to show a process of oxygen activation at a site of $\mathrm{Bi}-\square(-\mathrm{Ce})_{3}$.

The principal role of the Bi-doping in the improvement of catalytic activity is to modify the properties of the oxygen vacancies, allowing oxygen easy come, easy go. When the oxygen is removed, the $\mathrm{Bi}-\square(-\mathrm{Ce})_{3}$ cluster has a special electronic structure and an interesting improved redox property. Let us start with $\mathrm{Bi}^{3+}-\square\left(-\mathrm{Ce}^{3+}\right)_{3}$ (Figure 11a). The vacancy is favorable to $\mathrm{Bi}^{3+}$ as far as the coordination number is considered, but not to cerium cations, which prefers eight coordination. Therefore, it is still easy to adsorb oxygen. The adsorbed oxygen gains electrons from $\mathrm{Ce}^{3+}$ cations, forming a cluster of $\mathrm{Bi}^{3+}-\mathrm{O}\left(-\mathrm{Ce}^{4+}\right)_{3}$ (Figure 11b). 
The occupation of the vacancy favors $\mathrm{Ce}^{4+}$, but generates a too high coordination number for $\mathrm{Bi}^{3+}$, and an unbalanced charge at $\mathrm{Bi}^{3+}$. The oxygen intends to leave as an anion, reacting with $\mathrm{H}_{2} \mathrm{O}$, leading to the formation of a $\mathrm{Bi}^{3+}-\square\left(-\mathrm{Ce}^{4+}\right)_{3}$ cluster (Figure 11c). At this stage, electrons may transfer from the Pt nanoparticles to reduce the $\mathrm{Ce}^{4+}$ cations to stabilize the cluster, returning back to $\mathrm{Bi}^{3+}-\square\left(-\mathrm{Ce}^{3+}\right)_{3}$. This three-step circle demonstrates how the oxygen vacancies activate oxygen from the solution and how a potential of electron transfer from Pt to the clusters is created.

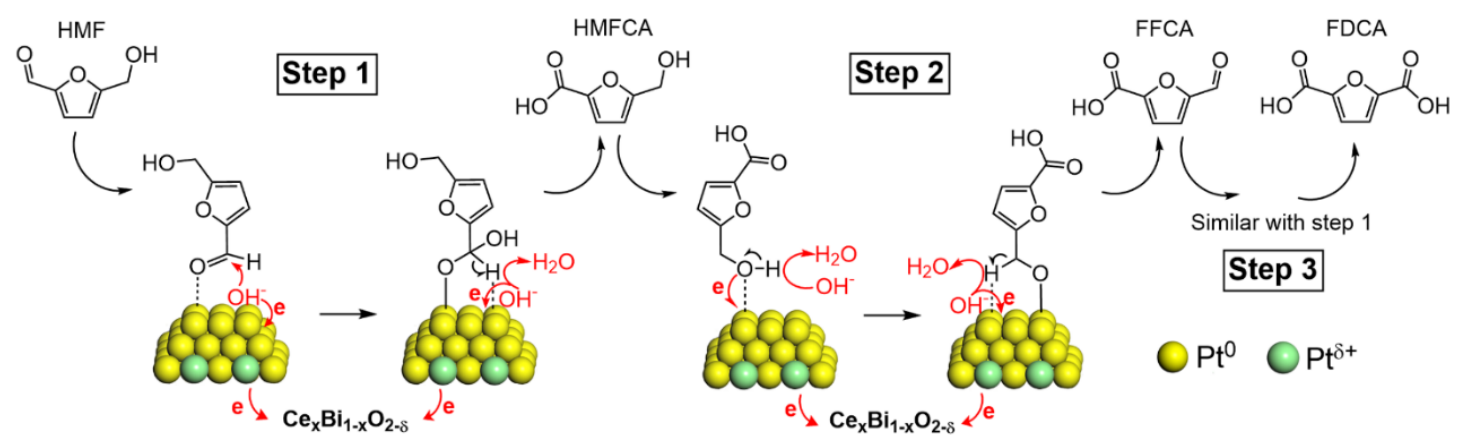

Scheme 1. Proposed mechanism for the oxidation reactions from HMF to FDCA on a Pt/3DOM$\mathrm{Ce}_{\mathrm{x}} \mathrm{Bi}_{1-\mathrm{x}} \mathrm{O}_{2-\delta}$ catalyst.

On the other hand, $3 \mathrm{DOM}-\mathrm{CeO}_{2}$ and $3 \mathrm{DOM}-\mathrm{Ce}_{0.8} \mathrm{Bi}_{0.2} \mathrm{O}_{2-\delta}$ in absence of Pt nanoparticles exhibit extremely lower catalytic performance for HMF oxidation as listed in Table 3 (entries 6 and 7). About $40 \% \sim 50 \%$ of HMF converted to side products through ketonization and condensation reactions. ${ }^{[17,56]}$ This can be understood that the $\mathrm{Bi}^{3+}-\mathrm{O}\left(-\mathrm{Ce}^{4+}\right)_{3}$ clusters cannot be selfreduced to $\mathrm{Bi}^{3+}-\mathrm{O}\left(-\mathrm{Ce}^{3+}\right)_{3}$ without receiving electron from other parts of the particle. Therefore, the aerobic oxidation of HMF must occur on the Pt nanoparticles, leaving electrons there. The electrons are then donated to the $\mathrm{Bi}^{3+}-\mathrm{O}\left(-\mathrm{Ce}^{4+}\right)_{3}$ clusters in the carrier. The clusters play unambiguously an important role in synergistic promoting the reaction. The hole rich $\mathrm{Pt}$ 
nanoparticles have a potential to attract $\mathrm{OH}^{-}$anions and HMF molecules, resulting in the continuous oxidation of HMF towards FDCA through dehydrogenation reactions on the surface of Pt nanoparticles. A more detailed process of the reactions is depicted in Scheme 1.

\subsection{Effect of 3DOM structure.}

In order to investigate the influence of 3DOM structure on the catalytic performance of these catalysts, the nanosized $\mathrm{Pt} / \mathrm{Ce}_{1-\mathrm{x}} \mathrm{Bi}_{\mathrm{x}} \mathrm{O}_{2-\delta}$ catalysts were also evaluated in the oxidation of $\mathrm{HMF}$ under the same reaction conditions. The reaction results are shown in Figure S10. It can be found from Figure 9 and Figure $\mathrm{S} 10$, the $\mathrm{Pt} / 3 \mathrm{DOM}-\mathrm{Ce}_{1-\mathrm{x}} \mathrm{Bi}_{\mathrm{x}} \mathrm{O}_{2-\delta}$ catalysts exhibit notably improved catalytic performance in the oxidation of HMF compared with $\mathrm{Pt} / \mathrm{Ce}_{1-x} \mathrm{Bi}_{\mathrm{x}} \mathrm{O}_{2-\delta}$. Especially for the yield of FDCA, the 3DOM samples show a significantly higher selectivity than the non-porous samples when the Bi-doping levels are the same. For instance, as seen in Figures 9c and S10c, although comparable HMF conversions were obtained over $\mathrm{Pt} / 3 \mathrm{DOM}-\mathrm{Ce}_{0.8} \mathrm{Bi}_{0.2} \mathrm{O}_{2-\delta}$ and $\mathrm{Pt} / \mathrm{Ce}_{0.8} \mathrm{Bi}_{0.2} \mathrm{O}_{2-\delta}$ catalysts, an obviously increased FDCA yield was achieved by the former for 10 h (100\%) compared with the latter (78\%). The improved FDCA yield can be attributed to the 3DOM structure of these catalysts. Firstly, the surface of the ordered macroporous structure may contain more defects created during the calcination to decompose PMMA, and become more suitable to house active Pt nanoparticles. Secondly, the inter-connected and ordered macroporous structure can significantly facilitate the mass transfer of the reactants and products and, therefore, can promote the multi-step oxidation reaction of HMF.

\subsection{Reusability of the catalyst.}

The stability of the $\mathrm{Pt} / 3 \mathrm{DOM}-\mathrm{Ce}_{1-\mathrm{x}} \mathrm{Bi}_{\mathrm{x}} \mathrm{O}_{2-\delta}$ catalysts in the aerobic oxidation of HMF was investigated using $\mathrm{Pt} / 3 \mathrm{DOM}-\mathrm{Ce}_{0.8} \mathrm{Bi}_{0.2} \mathrm{O}_{2-\delta}$ as a model catalyst. After each oxidation run, the catalyst was recovered by filtration, thoroughly washed with ethanol, and then dried at $50{ }^{\circ} \mathrm{C}$. In 
order to detect the actual stability of the catalyst, the reaction time of $6 \mathrm{~h}$ in each run was chosen, because the oxidation reaction was still in progress at this reaction time. The results of five consecutive cycle experiments are shown in Figure 12. It can be seen that $\mathrm{Pt} / 3 \mathrm{DOM}-\mathrm{Ce}_{0.8} \mathrm{Bi}_{0.2} \mathrm{O}_{2}$ $\delta$ exhibits excellent reusability in the aerobic oxidation of HMF. $100 \%$ of HMF conversion and $90 \%$ of FDCA yield are achieved in the fifth cycle, which are comparable with the results in the first cycle (100\% of HMF conversion and $89 \%$ of FDCA yield). The reaction solution catalyzed by $\mathrm{Pt} / 3 \mathrm{DOM}-\mathrm{Ce}_{0.8} \mathrm{Bi}_{0.2} \mathrm{O}_{2-\delta}$ was detected by ICP-AES after centrifuging for the separation of catalyst. Only $0.06 \%$ of Pt leaching was observed in the reaction solution of the first cycle, and no Pt leaching can be detected in the reaction solution of the second cycle. This indicates that the $\mathrm{Pt} / 3 \mathrm{DOM}-\mathrm{Ce}_{1-\mathrm{x}} \mathrm{Bi}_{\mathrm{x}} \mathrm{O}_{2-\delta}$ catalysts obtained in the present work are stable and can be reused at least five times without any notable loss in catalytic performance.

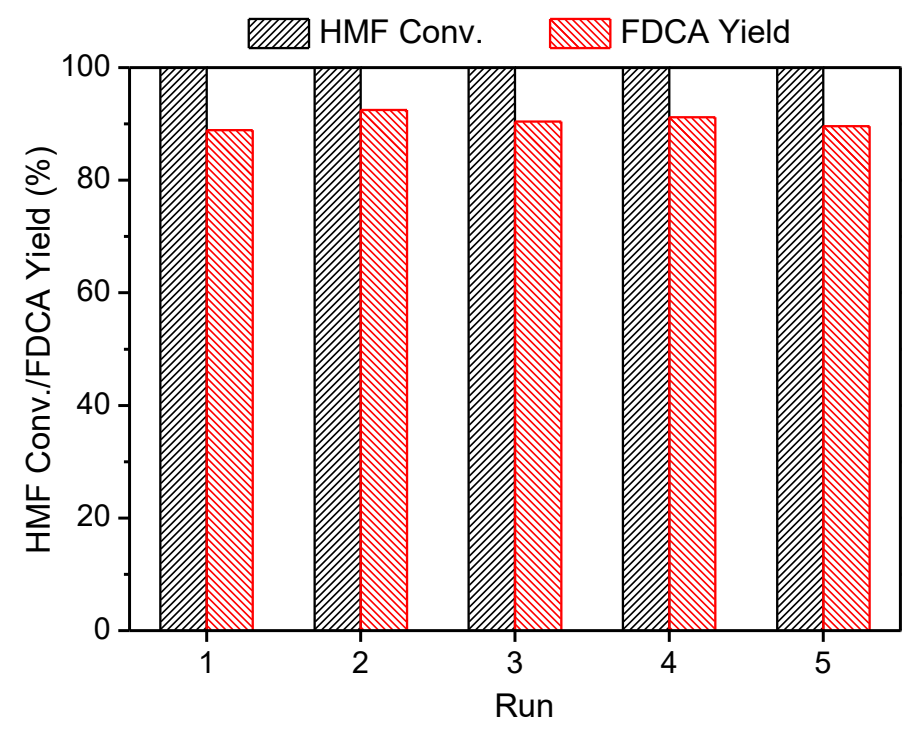

Figure 12. Recycling tests of $\mathrm{Pt} / 3 \mathrm{DOM}-\mathrm{Ce}_{0.8} \mathrm{Bi}_{0.2} \mathrm{O}_{2-\delta}$ for the aerobic oxidation of HMF. 


\section{Conclusion}

In summary, the principal role of the Bi-doping in the $\mathrm{Pt} / 3 \mathrm{DOM}-\mathrm{Ce}_{1-\mathrm{x}} \mathrm{Bi}_{\mathrm{x}} \mathrm{O}_{2-\delta}$ catalysts for the aerobic oxidation of HMF is to form an asymmetric environment of some oxygen vacancies, such as $\mathrm{Bi}-\square(-\mathrm{Ce})_{3}$. The chief advantage of these asymmetric clusters, in comparison with symmetric clusters, e.g. $(\mathrm{Ce}-)_{2} \square(-\mathrm{Ce})_{2}$ or the clusters containing more than one $\mathrm{Bi}^{3+}$ cation, is that both the occupied and unoccupied states at the oxygen sites in these clusters are metastable, making oxygen easy come, easy go. More importantly, in the oxygen adsorption/desorption circle at these clusters, oxygen molecules are reduced by taking electrons from the $\mathrm{Ce}^{3+}$ cations in the clusters, increasing the potential of electron transfer from the Pt nanoparticles to these clusters. It is obvious that the Bi-doping effect on the promotion of catalytic properties is not simply increasing the number of oxygen vacancies, but more importantly modifying the environment of the oxygen vacancies. We anticipate that this work can shed light on the future investigation of electron transfer between catalytic nanoparticles and oxide substrates, and relevant mechanisms of many other catalytic processes.

\section{Acknowledgements}

We thank Prof. J.-Q. Yu for a useful discussion. This work was supported by Tianjin Municipal Natural Science Foundation (Grant 17JCYBJC22600), China Scholarship Council (Grants 201606200096 and 201606200087), and the Fundamental Research Funds for the Central Universities. Computational support was provided by the Beijing Computing Center (BCC). 


\section{References:}

[1] Y. Lykhach, S. M. Kozlov, T. Skála, A. Tovt, V. Stetsovych, N. Tsud, F. Dvořák, V. Johánek, A. Neitzel, J. Mysliveček, S. Fabris, V. Matolín, K. M. Neyman, J. Libuda. Counting Electrons on Supported Nanoparticles. Nat. Mater. 15 (2016) 284-289.

[2] A. Bruix, J. A. Rodriguez, P. J. Ramírez, S. D. Senanayake, J. Evans, J. B. Park, D. Stacchiola, P. Liu, J. Hrbek, F. Illas. A New Type of Strong Metal-support Interaction and the Production of $\mathrm{H}_{2}$ through the Transformation of Water on $\mathrm{Pt} / \mathrm{CeO}_{2}$ (111) and $\mathrm{Pt} / \mathrm{CeO}_{\mathrm{x}} / \mathrm{TiO}_{2}(110)$ Catalysts. J. Am. Chem. Soc. 134 (2012) 8968-8974.

[3] C. T. Campbell. Electronic Perturbations. Nat. Chem. 4 (2012) 597-598.

[4] T. Montini, M. Melchionna, M. Monai, P. Fornasiero. Fundamentals and Catalytic Applications of $\mathrm{CeO}_{2}$-Based Materials. Chem. Rev. 116 (2016) 5987-6041.

[5] J. Ke, J. W. Xiao, W. Zhu, H. C. Liu, R. Si, Y. W. Zhang, C. H. Yan. Dopant-Induced Modification of Active Site Structure and Surface Bonding Mode for High-performance Nanocatalysts: CO Oxidation on Capping-free (110)-oriented $\mathrm{CeO}_{2}: \mathrm{Ln}$ ( $\left.\mathrm{Ln}=\mathrm{La}-\mathrm{Lu}\right)$ Nanowires. J. Am. Chem. Soc. 135 (2013) 15191-15200.

[6] H. Y. Kim, H. M. Lee, G. Henkelman. CO Oxidation Mechanism on $\mathrm{CeO}_{2}$-supported $\mathrm{Au}$ Nanoparticles. J. Am. Chem. Soc. 134 (2012) 1560-1570.

[7] E. Aneggi, D. Wiater, C. de Leitenburg, J. Llorca, A. Trovarelli. Shape-dependent Activity of Ceria in Soot Combustion. ACS Catal. 4 (2014) 172-181.

[8] Y. C. Wei, J. Liu, Z. Zhao, A. J. Duan, G. Y. Jiang. The Catalysts of Three-dimensionally Ordered Macroporous $\mathrm{Ce}_{1-\mathrm{x}} \mathrm{Zr}_{\mathrm{x}} \mathrm{O}_{2}$-supported Gold Nanoparticles for Soot Combustion: The Metal-support Interaction. J. Catal. 287 (2012) 13-29. 
[9] M. J. Beier, T. W. Hansen, J.-D. Grunwaldt. Selective Liquid-phase Oxidation of Alcohols Catalyzed by a Silver-based Catalyst Promoted by the Presence of Ceria. J. Catal. 266 (2009) $320-330$.

[10]M. Tamura, K. Tomishige. Redox Properties of $\mathrm{CeO}_{2}$ at Low Temperature: The Direct Synthesis of Imines from Alcohol and Amine. Angew. Chem. Int. Ed. 54 (2015) 864-867.

[11]M. E. Zakrzewska, E. Bogel-Łukasik, R. Bogel-Łukasik. Ionic Liquid-mediated Formation of 5-Hydroxymethylfurfural—A Promising Biomass-derived Building Block. Chem. Rev. 111 (2011) 397-417.

[12]R.-J. van Putten, J. C. van der Waal, E. de Jong, C. B. Rasrendra, H. J. Heeres, J. G. de Vries. Hydroxymethylfurfural, A Versatile Platform Chemical Made from Renewable Resources. Chem. Rev. 113 (2013) 1499-1597.

[13] G. Yong, Y. Zhang, J. Y. Ying. Efficient Catalytic System for the Selective Production of 5Hydroxymethylfurfural from Glucose and Fructose. Angew. Chem. Int. Ed. 47 (2008) 9345-9348.

[14]Z. Zhang, K. Deng. Recent Advances in the Catalytic Synthesis of 2,5-Furandicarboxylic Acid and Its Derivatives. ACS Catal. 5 (2015) 6529-6544.

[15]X. Zhang, K. Wilson, A. F. Lee. Heterogeneously Catalyzed Hydrothermal Processing of C5-C6 Sugars. Chem. Rev. 116 (2016) 12328-12368.

[16]A. J. J. E. Eerhart, A. P. C. Faaij, M. K. Patel. Replacing Fossil Based PET with Biobased PEF; Process Analysis, Energy and GHG Balance. Energy Environ. Sci. 5 (2012) 6407-6422.

[17]O. Casanova, S. Iborra, A. Corma. Biomass into Chemicals: Aerobic Oxidation of 5Hydroxymethyl-2-furfural into 2,5-Furandicarboxylic Acid with Gold Nanoparticle Catalysts. ChemSusChem 2 (2009) 1138-1144. 
[18]Z. Zhang, J. Zhen, B. Liu, K. Lv, K. Deng. Selective Aerobic Oxidation of the Biomassderived Precursor 5-Hydroxymethylfurfural to 2,5-Furandicarboxylic Acid under Mild Conditions over a Magnetic Palladium Nanocatalyst. Green Chem. 17 (2015) 1308-1317.

[19] X. Han, L. Geng, Y. Guo, R. Jia, X. Liu, Y. Zhang, Y. Wang. Base-free Aerobic Oxidation of 5-Hydroxymethylfurfural to 2,5-Furandicarboxylic Acid over a Pt/C-O-Mg Catalyst. Green Chem. 18 (2016) 1597-1604.

[20] S. Albonetti, A. Lolli, V. Morandi, A. Migliori, C. Lucarelli, F. Cavani. Conversion of 5Hydroxymethylfurfural to 2,5-Furandicarboxylic Acid over Au-based Catalysts: Optimization of Active Phase and Metal-support Interaction. Appl. Catal. B: Environ. 163 (2015) 520-530.

[21]Z. Miao, Y. Zhang, X. Pan, T. Wu, B. Zhang, J. Li, T. Yi, Z. Zhang, X. Yang. Superior Catalytic Performance of $\mathrm{Ce}_{1-x} \mathrm{Bi}_{x} \mathrm{O}_{2-\delta}$ Solid Solution and $\mathrm{Au} / \mathrm{Ce}_{1-x} \mathrm{Bi}_{x} \mathrm{O}_{2-\delta}$ for 5Hydroxymethylfurfural Conversion in Alkaline Aqueous Solution. Catal. Sci. Technol. 5 (2015) 1314-1322.

[22] A. Lolli, R. Amadori, C. Lucarelli, M. G. Cutrufello, E. Rombi, F. Cavani, S. Albonetti. Hardtemplate Preparation of $\mathrm{Au} / \mathrm{CeO}_{2}$ Mesostructured Catalysts and Their Activity for the Selective Oxidation of 5-Hydroxymethylfurfural to 2,5-Furandicarboxylic Acid. Micropor. Mesopor. Mater. 226 (2016) 466-475.

[23]Z. Miao, T. Wu, J. Li, T. Yi, Y. Zhang, X. Yang. Aerobic Oxidation of 5Hydroxymethylfurfural (HMF) Effectively Catalyzed by a $\mathrm{Ce}_{0.8} \mathrm{Bi}_{0.2} \mathrm{O}_{2-\delta}$ Supported Pt Catalyst at Room Temperature. RSC Adv. 5 (2015) 19823-19829.

[24]K. Yu, C. Zhang, Y. Chang, Y. Feng, Z. Yang, T. Yang, L.-L. Lou, S. Liu. Novel Threedimensionally Ordered Macroporous $\mathrm{SrTiO}_{3}$ Photocatalysts with Remarkably Enhanced Hydrogen Production Performance. Appl. Catal. B: Environ. 200 (2017) 514-520. 
[25] G. Kresse, J. Furthmüller. Efficiency of ab-initio Total Energy Calculations for Metals and Semiconductors Using a Plane-wave Basis Set. Comp. Mater. Sci. 6 (1996) 15-50.

[26] G. Kresse, J. Furthmüller. Efficient Iterative Schemes for ab initio Total-energy Calculations Using a Plane-wave Basis Set. Phys. Rev. B. 54 (1996) 11169-11186.

[27]J. P. Perdew, Y. Wang. Accurate and Simple Analytic Representation of the Electron-gas Correlation Energy. Phys. Rev. B. 45 (1992) 13244-13249.

[28]Z. Yang, Q. Wang, S. Wei. D. Ma, Q. Sun. The Effect of Environment on the Reaction of Water on the Ceria(111) Surface: A DFT+U Study. J. Phys. Chem. C. 114 (2010) 14891-14899.

[29]C. Loschen, J. Carrasco, K.M. Neyman, F. Illas. First-principles LDA+U and GGA+U Study of Cerium Oxides: Dependence on the Effective U Parameter. Phys. Rev. B. 75 (2007) 5115.

[30] M. Nolan, S. Grigoleit, D. C. Sayle, S. C. Parker, G. W. Watson. Density Functional Theory Studies of the Structure and Electronic Structure of Pure and Defective Low Index Surfaces of Ceria. Surf. Sci. 576 (2005) 217-229.

[31] S. Fabris, S. de Gironcoli, S. Baroni, G. Vicario, G. Balducci. Taming Multiple Valency with Density Functionals: A Case Study of Defective Ceria. Phys. Rev. B. 71 (2005) 1102-1105.

[32] W. Z. Zhou. Defect Fluorite-related Superstructures in the $\mathrm{Bi}_{2} \mathrm{O}_{3}-\mathrm{V}_{2} \mathrm{O}_{5}$ System. J. Solid State Chem. 76 (1988) 290-300.

[33] X.-M. Zhang, Y.-Q. Deng, P. Tian, H.-H. Shang, J. Xu, Y.-F. Han. Dynamic Active Sites over Binary Oxide Catalysts: In situ/operando Spectroscopic Study of Low-temperature CO Oxidation over $\mathrm{MnO}_{\mathrm{x}}-\mathrm{CeO}_{2}$ Catalysts. Appl. Catal. B: Environ. 191 (2016) 179-191. 
[34] S. Ramana, B. G. Rao, P. Venkataswamy, A. Rangaswamy, B. M. Reddy. Nanostructured Mn-doped Ceria Solid Solutions for Efficient Oxidation of Vanillyl Alcohol. J. Mol. Catal. A: Chem. 415 (2016) 113-121.

[35]Y. Zhang, Y. Yang, J. Zheng, W. Hua, G. Chen. Effects of Oxidizing Additives on Optical Properties of $\mathrm{Bi}_{2} \mathrm{O}_{3}-\mathrm{B}_{2} \mathrm{O}_{3}-\mathrm{SiO}_{2}$ Glasses. J. Am. Ceram. Soc. 91 (2008) 3410-3412.

[36]F. Schröder, N. Bagdassarov, F. Ritter, L. Bayarjargal. Temperature Dependence of $\mathrm{Bi}_{2} \mathrm{O}_{3}$ Structural Parameters Close to the $\alpha-\delta$ Phase Transition. Phase Transit. 83 (2010) 311-325.

[37] M. Guo, J. Lu, Y. Wu, Y. Wang, M. Luo. UV and Visible Raman Studies of Oxygen Vacancies in Rare-earth-doped Ceria. Langmuir 27 (2011) 3872-3877.

[38]M. A. Henderson, C. L. Perkins, M. H. Engelhard, S. Thevuthasan, C. H. F. Peden. Redox Properties of Water on the Oxidized and Reduced Surfaces of $\mathrm{CeO}_{2}$ (111). Surf. Sci. 526 (2003) $1-18$.

[39]L. Óvári, S. Krick Calderon, Y. Lykhach, J. Libuda, A. Erdőhelyi, C. Papp, J. Kiss, H.-P. Steinrück. Near Ambient Pressure XPS Investigation of the Interaction of Ethanol with Co/ $\mathrm{CeO}_{2}$ (111). J. Catal. 307 (2013) 132-139.

[40] S. Zhan, H. Zhang, Y. Zhang, Q. Shi, Y. Li, X. Li. Efficient $\mathrm{NH}_{3}-\mathrm{SCR}$ Removal of $\mathrm{NO}_{\mathrm{x}}$ with Highly Ordered Mesoporous $\mathrm{WO}_{3}(\chi)-\mathrm{CeO}_{2}$ at Low Temperatures. Appl. Catal. B: Environ. 203 (2017) 199-209.

[41]N. Jabeen, Q. Xia, S. V. Savilov, S. M. Aldoshin, Y. Yu, H. Xia. Enhanced Pseudocapacitive Performance of $\alpha-\mathrm{MnO}_{2}$ by Cation Preinsertion. ACS Appl. Mater. Inter. 8 (2016) $33732-33740$.

[42] S. M. Kozlov, K. M. Neyman. Effects of Electron Transfer in Model Catalysts Composed of Pt Nanoparticles on $\mathrm{CeO}_{2}(111)$ Surface. J. Catal. 344 (2016) 507-514. 
[43] W. Z. Zhou. Defect Fluorite Superstructures in the $\mathrm{Bi}_{2} \mathrm{O}_{3}-\mathrm{WO}_{3}$ System. J. Solid State Chem. 108 (1994) 381-394.

[44]J. Yang, C.-Q. Lv, Y. Guo, G.-C. Wang. A DFT+U Study of Acetylene Selective Hydrogenation on Oxygen Defective Anatase (101) and Rutile (110) $\mathrm{TiO}_{2}$ Supported Pd4 Cluster. J. Chem. Phys. 136 (2012) 104107.

[45] Y. Wang, K. Yu, D. Lei, W. Si, Y. Feng, L.-L. Lou, S. Liu. Basicity-Tuned HydrotalciteSupported Pd Catalysts for Aerobic Oxidation of 5-Hydroxymethyl-2-furfural under Mild Conditions. ACS Sustainable Chem. Eng. 4 (2016) 4752-4761.

[46]D. Lei, K. Yu, M.-R. Li, Y. Wang, Q. Wang, T. Liu, P. Liu, L.-L. Lou, G. Wang, S. Liu. Facet Effect of Single-Crystalline Pd Nanocrystals for Aerobic Oxidation of 5-Hydroxymethyl-2furfural. ACS Catal. 7 (2017) 421-432.

[47]S. Siankevich, G. Savoglidis, Z. Fei, G. Laurenczy, D.T. L. Alexander, N. Yan, P. J. Dyson, A Novel Platinum Nanocatalyst for the Oxidation of 5-Hydroxymethylfurfural into 2,5Furandicarboxylic Acid Under Mild Conditions. J. Catal. 315 (2014) 67-74.

[48]H. Ait Rass, N. Essayem, M. Besson, Selective Aqueous Phase Oxidation of 5Hydroxymethylfurfural to 2,5-Furandicarboxylic Acid over Pt/C Catalysts: Influence of the Base and Effect of Bismuth Promotion. Green Chem. 15 (2013) 2240-2251.

[49]H. Ait Rass, N. Essayem, M. Besson, Selective Aerobic Oxidation of 5-HMF into 2,5Furandicarboxylic Acid with Pt Catalysts Supported on $\mathrm{TiO}_{2}-$ and $\mathrm{ZrO}_{2}-$ Based Supports. ChemSusChem 8 (2015) 1206-1217.

[50] R.F.W. Bader. Atoms in Molecules - A Quantum Theory. Oxford University Press, New York, 1990. 
[51]G. Henkelman, A. Arnaldsson, H. Jónsson, A Fast and Robust Algorithm for Bader Decomposition of Charge Density. Comp. Mater. Sci. 36 (2006) 354-360.

[52]D. Guo, G.-C. Wang. Partial Oxidation of Methane on Anatase and Rutile Defective $\mathrm{TiO}_{2}$ Supported Rh4 Cluster: A Density Functional Theory Study. J. Phys. Chem. C 121 (2017) $26308-26320$.

[53]S. E. Davis, B. N. Zope, R. J. Davis. On the Mechanism of Selective Oxidation of 5Hydroxymethylfurfural to 2,5-Furandicarboxylic Acid over Supported Pt and Au Catalysts. Green Chem. 14 (2012) 143-147.

[54]B. N. Zope, D. D. Hibbitts, M. Neurock, R. J. Davis. Reactivity of the Gold/Water Interface During Selective Oxidation Catalysis. Science 330 (2010) 74-78.

[55] Y. M. Choi, H. Abernathy, H.-T. Chen, M. C. Lin, M. Liu. Characterization of $\mathrm{O}_{2}-\mathrm{CeO}_{2}$ Interactions Using in situ Raman Spectroscopy and First-principle Calculations. ChemPhysChem 7 (2006) 1957-1963.

[56] S. E. Davis, L. R. Houk, E. C. Tamargo, A. K. Datye, R. J. Davis. Oxidation of 5Hydroxymethylfurfural over Supported Pt, Pd and Au Catalysts. Catal. Today 160 (2011) $55-60$. 